\title{
Ecosystem modeling analysis of size-structured phytoplankton dynamics in the York River estuary, Virginia (USA). I. Development of a plankton ecosystem model with explicit feedback controls and hydrodynamics
}

\author{
Yongsik Sin*, Richard L. Wetzel ${ }^{* *}$ \\ School of Marine Science, Virginia Institute of Marine Science (VIMS), College of William and Mary, Gloucester Point, \\ Virginia 23062, USA
}

\begin{abstract}
An ecosystem simulation model was developed to investigate potential mechanisms controlling the size-structured phytoplankton and nutrient dynamics in the mesohaline zone of the York River estuary. The model included 12 state variables in a unit volume $\left(\mathrm{m}^{3}\right)$ describing the distribution of carbon and nutrients (nitrogen, phosphorus) in the surface mixed layer. General size-scale relationships and density-dependent feedback control terms were used in the ecosystem model. Forcing functions included incident solar radiation, water temperature, wind stress, river flow and tide, which include advective transport and turbulent mixing. Advective transport and turbulent mixing were incorporated into the model explicitly without coupling to other hydrodynamic models. The ecosystem model was developed in Fortran90 using differential equations that were solved numerically using the fourth-order Runge-Kutta (explicit) technique. After calibrating the ecosystem model, forcing and state variables in the model were validated using pre-existing data and field data collected over an annual cycle. Model predictions for forcing and state variables generally followed the pattern of field observations and were within the range of field data. Model sensitivity analysis was also performed to examine how sensitive model output was to specified changes in parameter values. Model output was not sensitive to changes in most parameters, suggesting that the model is relatively robust. These results suggested that the model including explicit feedback controls and hydrodynamic processes captures plankton/nutrient dynamics and can be used for additional modeling analyses of phytoplankton and nutrient dynamics in the York River estuary, Virginia.
\end{abstract}

KEY WORDS: Ecosystem model $\cdot$ Hydrodynamic processes $\cdot$ Feedback controls $\cdot$ York River estuary

Resale or republication not permitted without written consent of the publisher

\section{INTRODUCTION}

For several decades, computer simulation models have been used to explore plankton dynamics in aquatic systems because of their ability to integrate

\footnotetext{
*Present address: Division of Ocean System Engineering Mokpo National Maritime University, 571-2 Chukyo-dong, Mokpo, Chonnan 530-729, S. Korea

${ }^{* *}$ Corresponding author. E-mail: dick@vims.edu
}

and synthesize a tremendous array of information. Models have been used to describe interactions between various components of the plankton community and their physical-chemical environments which would otherwise be difficult due to the complexity of the interactions. Complexity of the plankton food web has been addressed using allometric relationships, i.e. the size-dependence of plankton metabolic processes (e.g. Fenchel 1974, Peters 1983, Joint 1991). Incorporation of such general size-scale relationships for planktonic

() Inter-Research $2002 \cdot$ www.int-res.com 
dynamics has provided a straightforward approach for plankton ecosystem modeling efforts (e.g. Moloney \& Field 1991, Painting et al. 1993, Armstrong 1994, Tamsalu \& Ennet 1995). Density-dependent feedbackcontrol terms (Wiegert 1979) have also been documented as being superior to empirical equations for studying trophic interactions among biotic compartments in the microbial food web (Wetzel 1994).

In estuarine environments, plankton population dynamics are complex mainly due to freshwater and tidal energy inputs into the system. Physical processes including advection and diffusion play an important role in estuarine plankton population dynamics (Haas et al. 1981, Delgadillo-Hinojosa et al. 1997, Shen et al. 1999). In this context, incorporation of physical processes is essential in estuarine ecosystem process-modeling and the relationship between physical processes and plankton population-dynamics in coastal estuarine systems have received increasing attention (Peterson \& Festa 1984, Cloern 1991, Eldridge \& Sieracki 1993, Vidergar et al. 1993).

The US Environmental Protection Agency (EPA) Chesapeake Bay Program has supported biweekly to monthly samples of water quality and biological data along the York River estuary, Virginia (USA) since the mid-1980s. Chl a content of different size classes of phytoplankton (micro-, nano-, pico) were also determined during the yearly cycle between 1996 and 1997. The historic and field data showed that phytoplankton blooms have developed during winter-spring (dominated by large cells), followed by smaller summer blooms dominated by small-sized cells in the York River (Sin et al. 1999, 2000). Although a large database exists for the York River, no ecosystem nor sub-system models have been developed to synthesize and use the information to investigate potential mechanisms controlling phytoplankton and nutrient dynamics on seasonal time scales. The objectives of this study were to develop a realistic ecosystem model focusing on seasonal size-structured plankton dynamics that employed allometric relationships as well as density-dependent feedback-control terms and explicit hydrodynamics for the York River estuary.

\section{MATERIALS AND METHODS}

Conceptual structure of the model. The conceptual ecosystem model includes 12 state variables for describing the distribution of carbon and nutrients in the surface mixed-layer of the mesohaline zone in the York River estuary (Fig. 1). The state variables consist of autotrophs including pico- $(<3 \mu \mathrm{m})$, nano- $(>3$ and $<20 \mu \mathrm{m})$, and micro- $(>20 \mu \mathrm{m})$ phytoplankton; heterotrophs including bacteria, flagellates + ciliates, micro- zooplankton ( $>70$ and $<202 \mu \mathrm{m}$ ), and mesozooplankton $(>202 \mu \mathrm{m})$; the nutrients $\mathrm{NO}_{2}{ }^{-}+\mathrm{NO}_{3}{ }^{-}, \mathrm{NH}_{4}{ }^{+}$, and $\mathrm{PO}_{4}{ }^{-3}$, and non-living organic materials, DOC, and POC. Groupings of autotrophs and heterotrophs are based on cell size and ecological hierarchy; mixotrophy was not considered in the model.

Forcing functions include incident solar radiation, temperature, tide, wind stress, and river flow. Incident solar radiation and temperature were estimated using empirical equations for Gloucester Point, Virginia (Wetzel \& Meyers 1993). Salinity and wind stress data were collected by the Virginia Institute of Marine Science (VIMS) at Gloucester Point. Daily river discharge rates at the fall line were collected by the US Geological Survey. The surface boundary condition is specified by a zero flux condition for all state variables at the atmosphere-water interface. Vertical transport by advection and diffusion, sinking of organisms, and fluxes of nutrients were incorporated into the model as the bottom boundary condition, in which the flux of organisms and nutrients was specified by vertical exchange or sinking rate times biomass and nutrient flux from the bottom water respectively. Chl $a$ and nutrients collected from the bottom water over an annual cycle (Sin et al. 2000) were used as input data for the bottom boundary condition. The EPA Chesapeake Bay Program monitoring data for the York River were used as input data for the up-river boundary condition. The model was developed in Fortran90 (Microsoft ${ }^{\circledR}$ Fortran Power Station), and the differential equations were solved numerically using the fourth order Runge-Kutta (explicit) technique. Table 1 gives the variable names, symbols and units for the forcing functions, state variables and boundary conditions used in the model.

Mathematical structure of hydrodynamic processes. The tidally-averaged model was simulated for plankton dynamics in the surface mixed-layer of the mesohaline zone in the York River estuary (Fig. 2). The surface mixed-layer depth, $z_{1}$ was determined by an empirical equation derived for the York River by Hayward et al. (1986):

$$
z_{1}=\exp \left(3.0666-0.6064 \delta S^{0.6528}\right)
$$

where $\delta S$ is the salinity difference between the surface and bottom waters. $\delta S$ was calculated as the top half of a sine wave (e.g. Eldridge \& Sieracki 1993):

$$
\delta S=\left|a \sin \left(\frac{2 \pi t}{\lambda}\right)\right|
$$

where $a$ is an amplitude of 5 psu and $\lambda$ is a period of $28 \mathrm{~d}$. Salinity gradients between the surface and bottom layers are influenced by neap and spring tidal cycles, with destratification of the water column occurring at high spring tides and stratification developing 


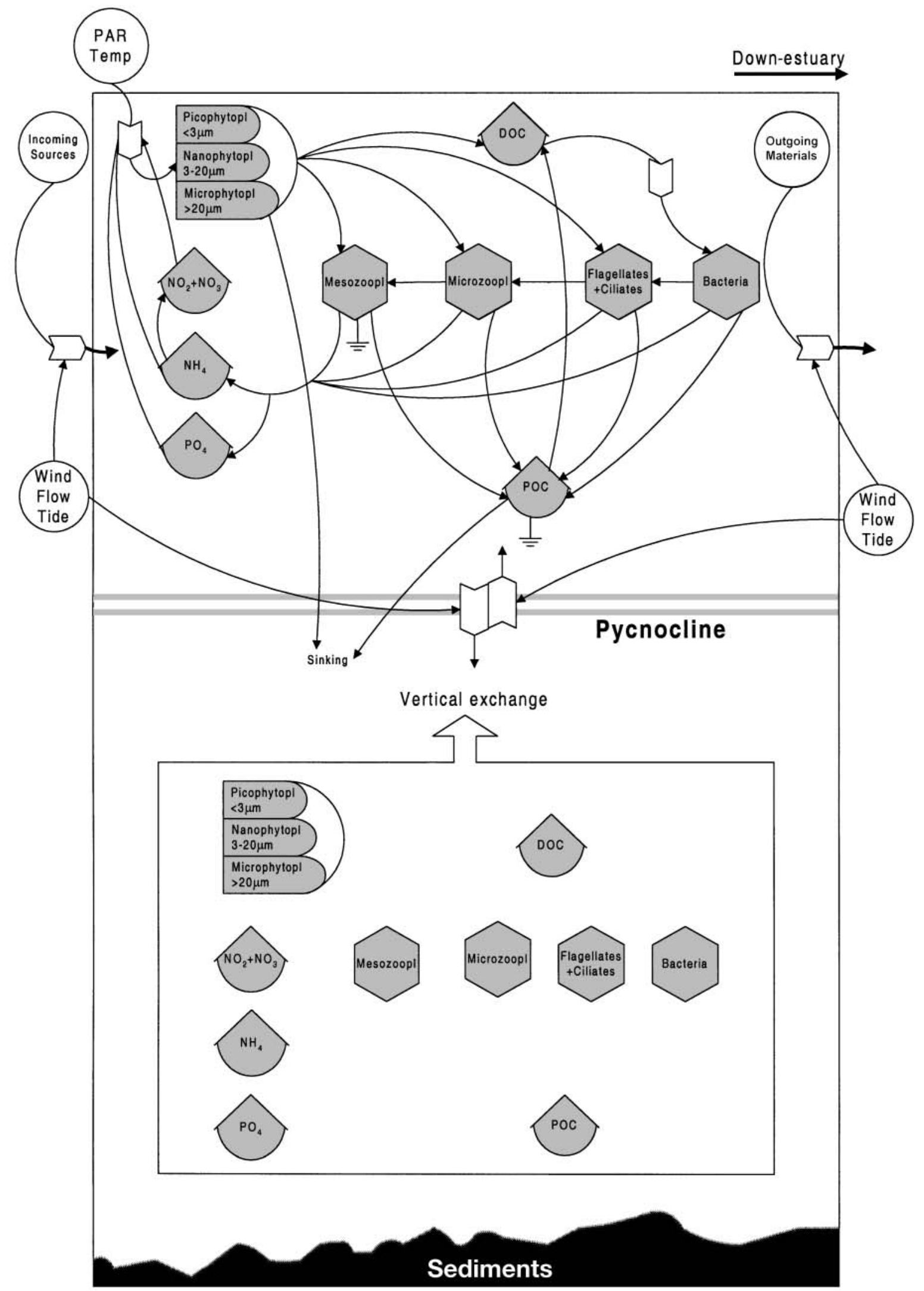

Fig. 1. Conceptual structure describing biological and chemical processes coupled with forcing functions for the plankton model of the York River system. Symbols follow those of Odum (1983) 
Table 1. Forcing functions, state variables and boundary conditions $(t=$ time) used in the ecosystem simulation model

\begin{tabular}{|c|c|c|}
\hline Variable & Symbol $^{\mathrm{a}}$ & Unit $^{\mathrm{b}}$ \\
\hline \multicolumn{3}{|l|}{ Forcing (or driving) variables } \\
\hline Incident radiation & $I(t)$ & $E \mathrm{~m}^{-2} \mathrm{~d}^{-1}$ \\
\hline Temperature & $T(t)$ & ${ }^{\circ} \mathrm{C}$ \\
\hline Salinity & $\mathrm{S}(t)$ & psu \\
\hline Wind & $U_{10}(t)$ & $\mathrm{cm} \mathrm{s}^{-1}$ \\
\hline Flow & $Q(t)$ & $\mathrm{m}^{3} \mathrm{~s}^{-1}$ \\
\hline \multicolumn{3}{|l|}{ State variables (components) } \\
\hline Picophytoplankton & $\mathrm{PP}(t)$ & $\mathrm{mg} \mathrm{chl} \mathrm{m}^{-3}$ \\
\hline Nanophytoplankton & $\mathrm{NP}(t)$ & $\mathrm{mgchl} \mathrm{m}^{-3}$ \\
\hline Microphytoplankton & $\mathrm{MP}(t)$ & $\mathrm{mgchl} \mathrm{m}^{-3}$ \\
\hline Heterotrophic bacteria & $\mathrm{HB}(t)$ & $\mathrm{gC} \mathrm{m}^{-3}$ \\
\hline Heterotrophic flagellates + ciliates & $\operatorname{HFC}(t)$ & $\mathrm{gC} \mathrm{m}^{-3}$ \\
\hline Microzooplankton & $\mathrm{Z} 1(t)$ & $\mathrm{gC} \mathrm{m}^{-3}$ \\
\hline Mesozooplankton & $\mathrm{Z} 2(t)$ & $\mathrm{gC} \mathrm{m} \mathrm{m}^{-3}$ \\
\hline Particulate organic carbon & $\operatorname{POC}(t)$ & $\mathrm{gC} \mathrm{m} \mathrm{m}^{-3}$ \\
\hline Dissolved organic carbon & $\operatorname{DOC}(t)$ & $\mathrm{gC} \mathrm{m}^{-3}$ \\
\hline Ammonium & $\mathrm{N} 1(t)$ & $\mu \mathrm{M}$ \\
\hline Nitrite + nitrate & $\mathrm{N} 2(t)$ & $\mu \mathrm{M}$ \\
\hline Orthophosphate & $\mathrm{P}(t)$ & $\mu \mathrm{M}$ \\
\hline \multicolumn{3}{|c|}{$\begin{array}{l}\text { Boundary specifications: } \\
\text { Fluxes of state variables }=0 \text { at interface of atmosphere- } \\
\text { surface water; fluxes = sinking, vertical exchange at } \\
\text { interface of surface mixed-layer and bottom layer; and } \\
\text { flows }=\operatorname{inflow}\left(Q_{\mathrm{i}}\right) \text { and outflow }\left(Q_{0}\right) \text { of surface layer }\end{array}$} \\
\hline \multicolumn{3}{|c|}{ aAll state variables are a function of time } \\
\hline
\end{tabular}

during the intervening periods in the York River (Haas 1975).

Table 2 presents the differential equations for the state variables and the symbols employed are given in Table 3. As described in Table 2, every state variable is affected by advective transport and turbulent mixing. Longitudinal transport in the surface mixedlayer is determined by the residual velocities $\left(\mathrm{m} \mathrm{s}^{-1}\right)$ of incoming $\left(Q_{\mathrm{i}}\right)$ and outgoing (river flow + estuarine circulation, $Q_{0}$ ) flows through the layer as shown in the second terms on the lefthand side of the equations. The flow $\left(Q_{\mathrm{i}}\right)$ entering and flow $\left(Q_{0}\right)$ leaving Section $n$ (Fig. 2) are estimated from the basin equation (Eq. 3 Pritchard 1965), where $Q_{k}$ is incoming $\left(Q_{\mathrm{i}}\right)$ or outgoing $\left(Q_{0}\right)$ flow, $B S_{k}$ is bottom salinity at Face i or o, $S S_{k}$ is surface salinity at Face $\mathrm{i}$ or $\mathrm{o}$, and $R D_{k}$ is vertically integrated river flow at Face $\mathrm{i}$ or $\mathrm{o}_{\text {; the }}$ basin equation is based on the assumption of steady state with water volume and salt:

$$
Q_{\mathrm{k}}=\frac{B S_{k}}{B S_{k}-S S_{k}} R D_{k}
$$

The surface and bottom salinities in the Face $i$ and o were estimated based on a 20 yr data record for the York River (Wojcik 1981). Vertically integrated riverdischarge rates in Face i were predicted by running a 1-D hydrodynamic model (developed by J. Shen at VIMS) under 6 different river-discharge rates at the fall line of the York River. In order to account for effects of river-discharge rates at the fall line $\left(R D_{\mathrm{fl}}\right)$, the vertically integrated river-discharge rates in Face i were predicted by using the correlation $\left(\mathrm{r}^{2}=0.98\right)$ between the prediction and river-discharge rate at the fall line $\left(R D_{\mathrm{fl}}\right)$ as input data in the hydrodynamic model. The vertically integrated river-discharge rate in Face i was assumed to equal that in Face o:

$$
R D_{k}=1.384 R D_{\mathrm{fl}}+2.62
$$

Vertical advection is governed by the upward velocity $(w)$ in the vertical axis $(z)$, as shown in the third terms on the left hand side of the equations in Table 2 . The upward velocity was determined by dividing the interface area $\left(\mathrm{m}^{2}\right)$ between surface mixed and bottom layers into the upward flow $\left(Q_{\mathrm{up}}, \mathrm{m}^{3} \mathrm{~s}^{-1}\right)$ which is determined by subtracting the outgoing flow $\left(Q_{0}\right)$ from the incoming flow $\left(Q_{\mathrm{i}}\right)$ (see Fig. 2).

Turbulent mixing is governed by the empirical equation for the diffusion coefficient $(D)$ (Denman \& Gargett 1983):

$$
D=0.25 \varepsilon N^{-2}
$$
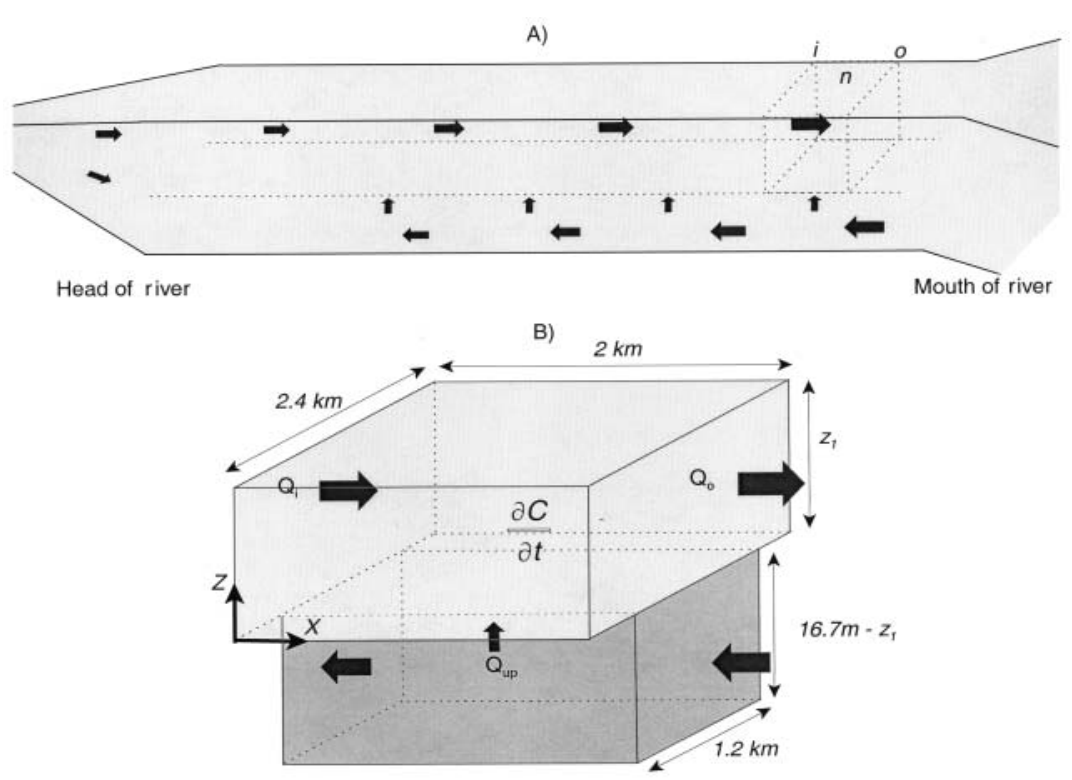

Fig. 2. (A) Schematic representation of net transport in an estuarine system and (B) geometric structure of the ecosystem model developed for this study. The surface mixed-layer depth, $z_{1}$, was determined by an empirical equation for the York River (Eq. 1, Hayward et al. 1986) For explanation of the other terms, see 'Materials and methods' 
Table 2. Differential equations employed for the 12 state variables. Symbols are described in Table 3

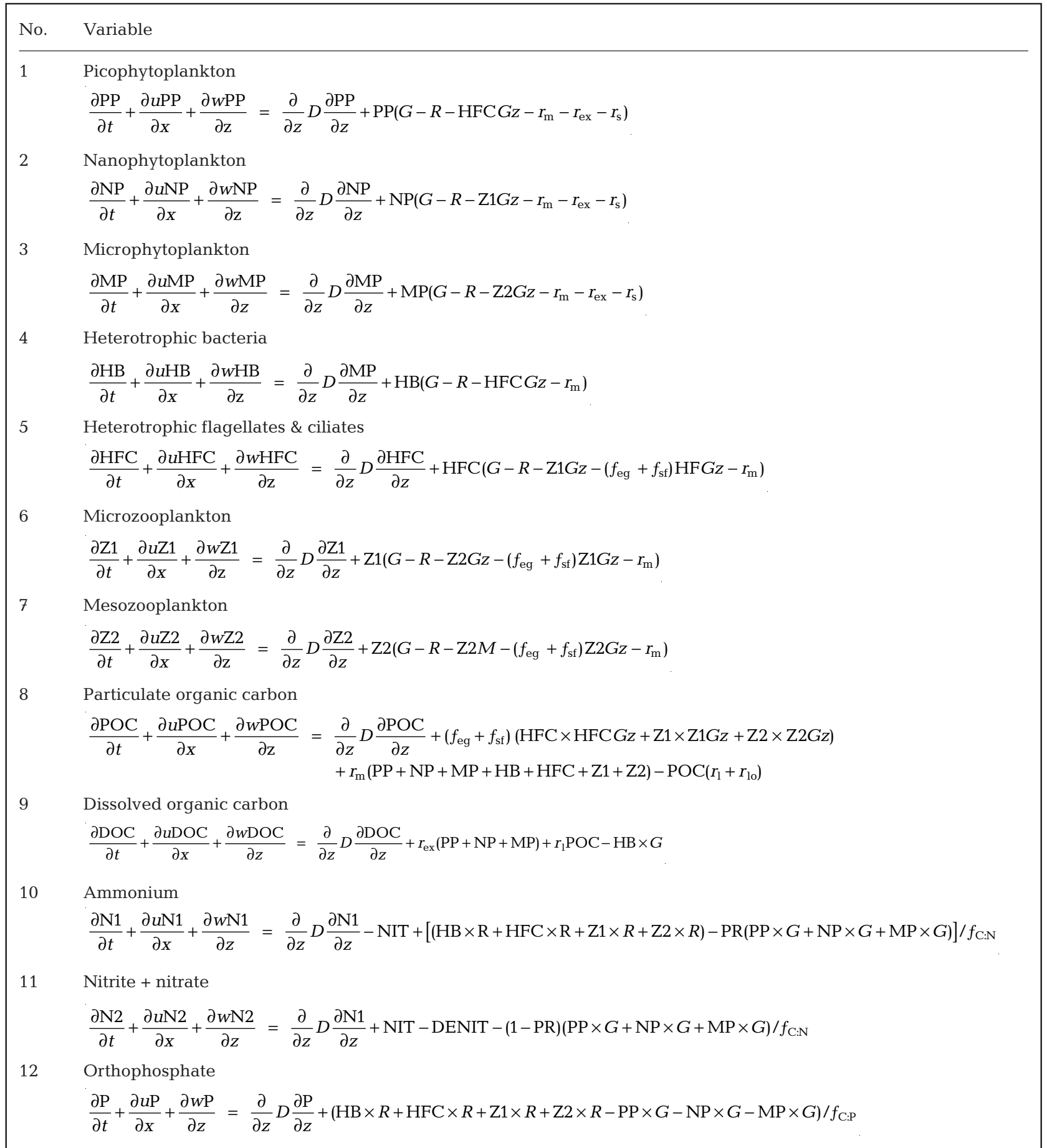

The rate of dissipation of turbulent kinetic energy, $\varepsilon$, is expressed as Eq. (6), and the buoyancy frequency, $N^{2}\left(\mathrm{~s}^{-1}=\right.$ radians $\mathrm{s}^{-1}$ ) as Eq. (7), where $\omega_{*}$ is turbulent frictional velocity $\left(\mathrm{m} \mathrm{s}^{-1}\right)$, $\kappa$ is von Karman's constant, $z_{1}, z_{2}$ are water depths of surface and bottom layers respectively, $u_{*}$ is bed-shear velocity $\left(0.01 \mathrm{~m} \mathrm{~s}^{-1}\right), g$ is the acceleration due to gravity, $\rho_{w}$ is the density of water, and $\partial \rho / \partial z$ is the vertical density gradient. In order to take into account the effects of bottom friction, $u_{*}$ (bed-shear velocity) was incorporated into the equation employed by Denman \& Gargett (1983), and typical values, i.e., $0.01 \mathrm{~m} \mathrm{~s}^{-1}$ (Young $\&$ Southard 1978) were chosen for model simulation: 
Table 3. Symbols and units of physical, biological and chemical processes incorporated in the model

\begin{tabular}{|c|c|c|}
\hline $\begin{array}{l}\text { Physical and } \\
\text { biochemical processes }\end{array}$ & Symbol & Unit \\
\hline $\begin{array}{l}\text { Residual velocity in } x, z \\
\text { direction }\end{array}$ & $u, w$ & $\mathrm{~m} \mathrm{~s}^{-1}$ \\
\hline Diffusion coefficient & $D$ & $\mathrm{~m}^{2} \mathrm{~s}^{-1}$ \\
\hline $\begin{array}{l}\text { Picophytoplankton } \\
\text { Gross production } \\
\text { Respiration }\end{array}$ & $\begin{array}{l}\operatorname{PPG}(t) \\
\operatorname{PP} R(t)\end{array}$ & $\begin{array}{l}g \mathrm{C} \mathrm{m} \mathrm{m}^{-3} \mathrm{~d}^{-1} \\
\mathrm{gC \textrm {m } ^ { - 3 }} \mathrm{d}^{-1}\end{array}$ \\
\hline $\begin{array}{l}\text { Nanophytoplankon } \\
\text { Gross production } \\
\text { Respiration }\end{array}$ & $\begin{array}{l}\operatorname{NPG}(t) \\
\operatorname{NP} R(t)\end{array}$ & $\begin{array}{l}g \mathrm{~g} \mathrm{~m}^{-3} \mathrm{~d}^{-1} \\
\mathrm{gC} \mathrm{m}^{-3} \mathrm{~d}^{-1}\end{array}$ \\
\hline $\begin{array}{l}\text { Microphytoplankon } \\
\text { Gross production } \\
\text { Respiration }\end{array}$ & $\begin{array}{l}\operatorname{MPG}(t) \\
\operatorname{MP} R(t)\end{array}$ & $\begin{array}{l}g \mathrm{~g} \mathrm{~m}^{-3} \mathrm{~d}^{-1} \\
\mathrm{gC} \mathrm{m}^{-3} \mathrm{~d}^{-1}\end{array}$ \\
\hline $\begin{array}{l}\text { Grazing by heterotrophic } \\
\text { flagellates + ciliates }\end{array}$ & $\operatorname{HFCGz}(t)$ & $\mathrm{gC} \mathrm{m}^{-3} \mathrm{~d}^{-1}$ \\
\hline $\begin{array}{l}\text { Grazing by microzoo- } \\
\text { plankton }\end{array}$ & $\mathrm{Z} 1 G z(t)$ & $\mathrm{gC} \mathrm{m}^{-3} \mathrm{~d}^{-1}$ \\
\hline $\begin{array}{l}\text { Grazing by mesozoo- } \\
\text { plankton }\end{array}$ & $\mathrm{Z} 2 G z(t)$ & $\mathrm{gC} \mathrm{m}^{-3} \mathrm{~d}^{-1}$ \\
\hline $\begin{array}{l}\text { Sinking rate of phyto- } \\
\text { plankton }\end{array}$ & $r_{\mathrm{s}}$ & $\mathrm{m} \mathrm{d}^{-1}$ \\
\hline $\begin{array}{l}\text { Exudation rate of phyto- } \\
\text { plankton }\end{array}$ & $r_{\mathrm{ex}}$ & $d^{-1}$ \\
\hline $\begin{array}{l}\text { Mortality rate of auto- } \\
\text { and heterotrophs }\end{array}$ & $r_{\mathrm{m}}$ & $d^{-1}$ \\
\hline $\begin{array}{l}\text { Heterotrophic bacteria } \\
\text { Gross production } \\
\text { Respiration } \\
\text { Excretion }\end{array}$ & $\begin{aligned} & \operatorname{HBG}(t) \\
& \operatorname{HB} R(t) \\
\text { N } & \text { or } f_{\mathrm{C}: \mathrm{P}} \mathrm{HB} R(t)\end{aligned}$ & 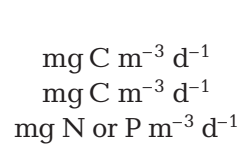 \\
\hline $\begin{array}{l}\text { Heterotrophic flagellate } \\
\text { Gross production } \\
\text { Respiration } \\
\text { Excretion } \quad f_{\mathrm{C}: \mathrm{N}}\end{array}$ & 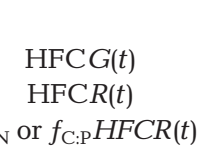 & 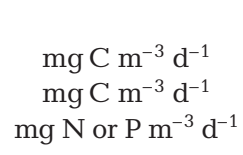 \\
\hline $\begin{array}{l}\text { Microzooplankton } \\
\text { Gross production } \\
\text { Respiration } \\
\text { Excretion }\end{array}$ & $\begin{array}{c}\mathrm{Z} 1 G(t) \\
\quad \mathrm{Z} 1 R(t) \\
\text { or } f_{\mathrm{C}: \mathrm{P}} \mathrm{Z} 1 R(t)\end{array}$ & 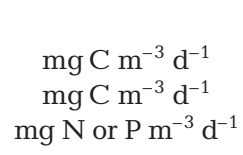 \\
\hline $\begin{array}{l}\text { Mesozooplankton } \\
\text { Gross production } \\
\text { Respiration } \\
\text { Excretion } \\
\text { Grazing by fishes }\end{array}$ & $\begin{array}{l}\mathrm{Z} 2 G(t) \\
\mathrm{Z} 2 R(t) \\
\text { or } f_{\mathrm{C}: \mathrm{P}} \mathrm{Z} 2 R(t) \\
\quad \mathrm{Z} 2 M\end{array}$ & 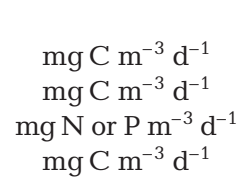 \\
\hline $\mathrm{C}: \mathrm{N}$ and $\mathrm{C}: \mathrm{P}$ ratios & $f_{\mathrm{C}: \mathrm{N}}$ or $f_{\mathrm{C}: \mathrm{P}}$ & dimensionless \\
\hline $\begin{array}{l}\text { Fraction of egestion } \\
\text { by grazers }\end{array}$ & $f_{\mathrm{eg}}$ & dimensionless \\
\hline $\begin{array}{l}\text { Fraction of sloppy feeding } \\
\text { by grazers }\end{array}$ & $f_{\mathrm{sf}}$ & dimensionless \\
\hline Leaching rate of POC & $r_{1}$ & $d^{-1}$ \\
\hline Grazing loss rate of POC & $r_{\mathrm{lo}}$ & $\mathrm{d}^{-1}$ \\
\hline Nitrification & $\operatorname{NIT}(t)$ & $\mathrm{gN} \mathrm{m}^{-3} \mathrm{~d}^{-1}$ \\
\hline Denitrification & $\operatorname{DENIT}(t)$ & $\mathrm{gN} \mathrm{m}^{-3} \mathrm{~d}^{-1}$ \\
\hline
\end{tabular}

$$
\begin{aligned}
& \varepsilon=\frac{\omega_{*}{ }^{3}}{\kappa z_{1}}+\frac{u_{*}{ }^{3}}{\kappa z_{2}} \\
& N^{2}=\frac{g}{\rho_{w}} \times \frac{\partial \rho}{\partial z}
\end{aligned}
$$

The turbulent frictional velocity, $\omega_{*}$ (Eq. 8), is a function of windstress $(\tau)$, air and water densities $\left(\rho_{a}=1.2 \mathrm{~kg} \mathrm{~m}^{-3}\right.$, $\rho_{\mathrm{w}}$, respectively), a drag coefficient $\left(C_{10}, 1.3 \times 10^{-3}\right)$, and the mean wind speed $10 \mathrm{~m}$ above the sea surface $\left(U_{10}\right)$. Water densities are determined by Eq. (9), where $\rho_{f}$ is the density of freshwater $\left(10^{3} \mathrm{~kg} \mathrm{~m}^{-3}\right), k$ is a constant, 7.5 $\times 10^{-4}$, and $S$ is salinity (Hamilton 1977):

where:

$$
\omega_{*}=\sqrt{\frac{\tau}{\rho_{\mathrm{w}}}}=\sqrt{\frac{\rho_{\mathrm{a}} C_{10} U_{10}{ }^{2}}{\rho_{\mathrm{w}}}}
$$

$$
\rho_{\mathrm{w}}=\rho_{f}(1+k S)
$$

Mathematical structure of biological and chemical processes. Phytoplankton population densities are determined by advective transport, turbulent mixing, gross growth rate, respiration rate, sinking rate, mortality (senescence) rate, exudation rate, and grazing rate by herbivores (Table 2). Gross growth, $G$ (Eq. 10) is limited by light (Ltlim) and nutrients (Ntlim) acting on the potential maximum growth rate $\left(G_{\max }\right)$, which is itself dependent on body size and temperature.

$$
G=G_{\max } \times \text { Ltlim } \times \text { Ntlim }
$$

Moloney \& Field (1989) presented a significant relationship between body mass $(M ; p g C)$ and maximal nutrient uptake rates of phytoplankton (Eq. 11). The effect of temperature on the maximum growth rates is also considered, since Eppley (1972) documented a significant relationship between temperature and an upper physiological limit to phytoplankton growth in conditions where neither light nor nutrients were in limited supply. The temperature effect $\left(T(t) / k_{\text {cal }}\right)$ is combined with Eq. (11) as a function of the surface water temperature, $T(t)$, and constant $k_{\mathrm{cal}}$ is defined as a calibration parameter:

$$
G_{\max }=3.6 \mathrm{M}^{-0.25}
$$

Light limitation is determined by $f, k_{\mathrm{d}}, z, I_{\mathrm{m}}$ and $I_{\mathrm{o}}$ as shown in Eq. (12) (DiToro et al. 1971), where $f$ is the photoperiod as a fraction of a day (e.g. 0.5 at the equinoxes), $k_{\mathrm{d}}$ is the light attenuation coefficient $\left(\mathrm{m}^{-1}\right)$, $z$ is the depth $(\mathrm{m})$, and $I_{\mathrm{m}}$ and $I_{\mathrm{o}}$ are incident average and optimal light $\left(\mathrm{E} \mathrm{m}^{-2} \mathrm{~d}^{-1}\right)$, respectively. Light attenuation $\left(k_{\mathrm{d}}\right)$ was measured over an annual cycle and used as input data. Daily $k_{\mathrm{d}}$ values were interpolated based on the field data which appear to be affected by riverdischarge rates, ranging from 1.10 to $2.61 \mathrm{~m}^{-1}$ (Sin et al. 2000). $I_{\mathrm{o}}$ can differ between size classes of phytoplankton, and was determined in the process of calibration for the York River ecosystem model: 


$$
L t L i m=\frac{\mathrm{e} \times f}{k_{\mathrm{d}} \times z}\left(\mathrm{e}^{-\frac{I_{m}}{I_{\mathrm{o}}} \cdot \mathrm{e}^{-k_{\mathrm{d}} z_{1}}}-\mathrm{e}^{-\frac{I_{m}}{I_{\mathrm{o}}}}\right)
$$

Nutrient limitation is detemined using the Monod (1942) model (Eq. 13). Eq. (14) gives the derivation for the half-saturation constant for each limiting nutrient. The half-saturation constant $\left(K_{\mathrm{N}}\right)$ for nitrogen is calculated using Moloney \& Field (1991) equations based on mean cell size (biovolume, $\mu^{3}$ ) which can be converted to cell mass $(M, \mathrm{pg} C) . K_{\mathrm{P}}$ is determined by dividing $K_{\mathrm{N}}$ by the N:P ratio:

where:

$$
N t \operatorname{Lim}=\min \left(\frac{\mathrm{N}}{K_{\mathrm{N}}+\mathrm{N}}, \frac{\mathrm{P}}{K_{\mathrm{P}}+\mathrm{P}}\right)
$$

$$
K_{\mathrm{N}}=2 M^{0.38}, \quad K_{\mathrm{P}}=\frac{K_{\mathrm{N}}}{\mathrm{N}: \mathrm{P}}
$$

Estimation of respiration is a function of surface water temperature $(T(t))$ and phytoplankton gross growth $(G)$ based on an empirical equation by (Biebl \& McRoy 1971):

$R=0.5\left[0.5 G(0.0104 T(t)+0.3432)+\mathrm{e}^{(0.1370 T(t)-10.09)}\right]$

Sinking rates of primary producers are based on allometric relationships (Moloney \& Field 1989), as $0.029 M^{0.42}$. Mortality (senescence) rate $\left(r_{\mathrm{m}}\right)$ and a constant fraction of DOC release (cf. Malone \& Ducklow 1990) by phytoplankton (exudation rate, $r_{\mathrm{ex}}$ ) were determined by model calibration, since equations or kinetics for the processes have not been well established.

Grazing by herbivores is based on an empirical, cellsize relationship between grazer and prey, and a preydensity function (given below). It is assumed that heterotrophs feed only on prey within a size range from 10 to 100 times smaller than themselves. The mathematical equations employed to describe the relationships are based on nonlinear, donor- and recipientcontrolled feedback equations developed by Wiegert (1973) and applied by Wiegert \& Wetzel (1979) and Wetzel \& Christian (1984). Trophic interactions between prey (or resource, i) and predator (or recipient, $j$ ) are regulated by feedback terms composed of 4 density-related parameters: $A_{i j}$, the resource (donor) density or concentration below which uptake by the recipient is limited; $G_{i j}$, the resource density or concentration at which the donor resource is not available to the recipient population; $A_{j j}$, the recipient density or concentration above which uptake of a resource is less than maximum (limited); $G_{j j}$, the maximum maintainable recipient density or concentration for a population when other resources are not limiting. It was assumed that the range in population densities observed over an annual and/or inter-annual sampling cycles in the York River estuary included threshold and limit levels of each compartment in the ecosystem model. Donorcontrolled $\left(f b_{i j}\right)$ and recipient-controlled $\left(f b_{j j}\right)$ feedback terms were determined by standing stocks of donor $\left(X_{i}\right)$ and recipient $\left(X_{j}\right)$ compartments, and the densitydependent parameters (Eq. 16). The feedback terms are constrained to range from 0 to 1 (maximum feedback-control) and are dimensionless:

$$
f b_{i j}=\left[1-\frac{X_{i}-G_{i j}}{A_{i j}-G_{i j}}\right], \quad f b_{j j}=\left[1-\frac{X_{j}-A_{j j}}{G_{j j}-A_{j j}}\right]
$$

The recipient-controlled feedback $\left(f b_{j j}\right)$ must be corrected to allow for uptake or consumption by a population at maximum density such that uptake or consumption by the recipient from donor compartments meets metabolic losses. The metabolic correction term $\left(C_{i j}\right)$ accounts for respiration $\left(R_{\text {het }}\right)$, egestion $\left(f_{\text {eg }}\right)$ and sloppy feeding $\left(f_{\mathrm{s} f}\right)$ of grazers as in Eq. (17), where $G z_{\max }$ is the maximum grazing rate (explained below).

$$
C_{i j}=1-\frac{R_{n e t}}{G z_{\max }\left[1-\left(f_{\mathrm{eg}}+f_{\mathrm{sf}}\right]\right.}
$$

The correction term is incorporated into the total multiplicative feedback terms $\mathrm{TF}_{\mathrm{ij}}$, combining both donorand recipient-controlled controls as Eq. (18), where $f b_{i j}{ }^{\prime}$ are prime values of $f b_{i j}$, and determined as $1-f b_{i j}$. Nomenclatures $i$ and $j$ follow the numbers of state variables shown in Table 2 in the description of energy flow below, where ' $i$ ' is the donor and ' $j$ ' is the recipient compartment respectively:

$$
T F_{i j}=1-\left[f b_{i j}^{\prime}\left(1-f b_{j j} \times C_{i j}\right)\right]
$$

Heterotrophic bacterial production is determined by gross growth, respiration, and grazing (Table 2). Bacterial growth $\left(G_{\mathrm{b}}\right)$ was a function of bacterial maximum growth rates $\left(G_{\mathrm{b}_{\max }}\right)$, bacterial density $\left(X_{4}\right)$ and total multiplicative feedback-control $\left(T F_{i j}\right)$ on DOC uptake by bacteria:

$$
G_{b}=G_{b_{\max }} \times X_{4}\left(1-T F_{i j}\right)
$$

where $G_{\mathrm{b}_{\max }}$ was derived as for phytoplankton growth maximum rate (Eq. 11). Respiration rate (Eq. 20) is estimated by a function of basal respiration $\left(b r_{b}, 0.5 \mathrm{~d}^{-1}\right)$, bacterial density, recipient-controlled feedback term $\left(f b_{i j}\right)$ and a fraction $(40 \%)$ of bacterial gross growth, $G_{\mathrm{b}}$ (see Eldridge \& Sieracki, 1993):

$$
R_{\mathrm{b}}=b r_{\mathrm{b}} \times X_{4} \times f b_{i j}+0.4 G_{\mathrm{b}}
$$

The 'assimilation efficiency' of bacteria is assumed to be $100 \%$.

The 'other' heterotrophs represented in the model have a similar structure for controlling factors: advective transport, turbulent mixing, gross growth, grazing by higher-level consumers, respiration, egestion and sloppy feeding. Gross growth, $G_{\text {het }}$ (Eq. 21) is determined as a function of flux preference $\left(T P_{i j}\right)$, maximum grazing rate $\left(G z_{\max }\right)$, predator compartments $\left(X_{j}\right)$, and 
total multiplicative feedback $\left(T F_{i j}\right)$ on energy flow from prey to grazer or predator:

$$
G_{\text {het }}=T P_{i j} \times G z_{\max } \times X_{j}\left(1-T F_{i j}\right)
$$

$G z_{\max }$ was determined by cell size of each size class (computed as $63 M_{\text {het }}{ }^{-0.25}$ where $M$ equals mass of the heterotroph in pg). $T P_{i j}$ is a function of feeding preference $\left(P_{i j}\right)$, flux preference value $\left(P D_{j}\right)$ and the donorcontrolled feedback term $\left(f b_{i j}\right)$ :

$$
T P_{i j}=P_{i j} \times P D_{j}\left(1-f b_{i j}\right)
$$

Feeding preference was considered since each predator has 2 classes of potential prey (autotrophs vs heterotrophs) as shown in Fig. 1.

Respiration of grazers $\left(R_{\text {het }}\right)$ is estimated as a function of a basal respiration rate $\left(b r_{\text {het }} 0.4 \mathrm{~d}^{-1}\right)$, grazer density $\left(X_{j}\right)$, recipient-controlled feedback of the grazerpredator $\left(f b_{j j}\right)$ and fraction $(30 \%)$ of the gross growth $\left(G_{\text {het }}\right)$ of grazer-predator (Eq. 23):

$$
R_{\text {het }}=b r_{\text {het }} \times X_{j} \times f b_{j j}+0.3 G_{\text {het }}
$$

Grazers egest a proportion of ingested matter as faeces as well as respiration; $10 \%$ of ingested materials is assumed to be egested as faeces (cf. Barthel 1983, Miller \& Landry 1984).

POC dynamics were determined by inputs from advective transport, turbulent mixing, mortality (senescence) rate of plankton, egestion rate of grazers, rate of sloppy feeding and losses due to leaching rate of POC and uptake by higher-level consumers (Table 2). Sloppy feeding and grazing loss to zooplankton were defined as calibration parameters.

DOC concentrations were regulated by advective transport, turbulent mixing, exudation of phytoplankton, lysis of POC (leaching) and uptake by bacteria. Leaching rate was determined by calibration within the range of literature values (Kristensen 1994).

Ambient nutrient concentrations are determined by advective transport, turbulent diffusion and phytoplankton uptake rates and excretion rates of heterotrophs, as shown in Table 2. Uptake rates of nutrients by phytoplankton are calculated by dividing gross growth rates $(G)$ by C:nutrient ratios; $G / \mathrm{C}: \mathrm{N}_{t}$. Assuming that phytoplankton prefer ammonium $\left(\mathrm{NH}_{4}^{+}\right)$as their source of $\mathrm{N}$, the preference $(P R)$ was determined as a function of concentrations of ammonium $\left(\mathrm{NH}_{4}\right)$ and nitrite + nitrate $\left(\mathrm{NO}_{\mathrm{x}}\right)$ concentrations and the half saturation constant $\left(K_{\mathrm{N}}\right)$ for nitrogen (Thomann \& Fitzpatrick 1982:

$$
P R=\left[\mathrm{NH}_{4}\right] \frac{\left[\mathrm{NO}_{\mathrm{x}}\right]}{\left(K_{\mathrm{N}}+\left[\mathrm{NH}_{4}\right]\right)\left(K_{\mathrm{N}}+\left[\mathrm{NO}_{\mathrm{X}}\right]\right)}+\frac{\left[\mathrm{NH}_{4}\right] \times K_{\mathrm{N}}}{\left(\left[\mathrm{NH}_{4}\right]+\left[\mathrm{NO}_{\mathrm{X}}\right]\right)\left(K_{\mathrm{N}}+\left[\mathrm{NO}_{\mathrm{X}}\right]\right)}
$$

The preference for ammonium is unity when nitrate is absent, whereas it is zero when ammonium is absent. The preference approaches unity when both ammonium and nitrite + nitrate are abundant, whereas it decreases when ammonium is scarce but nitrite + nitrate is abundant. The use of nitrite + nitrate is not terminated when ammonium is abundant and nitrite + nitrate is scarce until nitrite + nitrate is completely depleted.

Excretion rates of heterotrophs are determined by respiration rates $\left(R_{\mathrm{het}}\right)$ and C:nutrient ratios; $R_{\mathrm{het}} / \mathrm{C}: \mathrm{N}_{t}$. For the nitrogen pool, it was assumed that heterotrophs only excrete ammonium; however, nitrification of ammonium is a source for nitrite + nitrate, as well as input through turbulent mixing. Nitrification (NIT) was determined by a temperature-dependent mechanism as in Eq. (25) (Jaworski et al. 1972), where time is

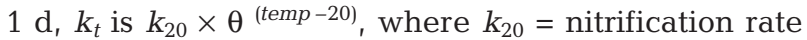
at $20^{\circ} \mathrm{C}\left(0.068 \mathrm{~d}^{-1}\right)$, and $\theta=$ constant for temperature adjustment of the nitrification rate (1.188):

$$
\text { NIT }=\left[\mathrm{NH}_{4}{ }^{+}\right] \times \exp \left(k_{t} \times \text { time }\right)
$$

Denitrification was assumed to be $10 \%$ of the nitrite + nitrate concentrations (e.g. Nowicki et al. 1997).

Model calibration and validation. The ecosystem model was calibrated by adjusting values of parameters which were not specified by the literature or field observations from the York River estuary. These parameters included optimal light intensity for pico-, nano- and microphytoplankton, mortality rate of phytoplankton, exudation rate of phytoplankton, leaching rate of POC, grazing loss rate of $\mathrm{POC}$, fraction of sloppy feeding, fraction of egestion by grazers, mortality rate of mesozooplankton, bed-shear velocity, grazer preference for phytoplankton and heterotrophs (bacteria, flagellate + ciliates and microzooplankton) (see Appendix 1).

Field data collected over an annual cycle from the York River were used as validation data for the 3 size-structured phytoplankton populations and for nutrients (Sin 1998). Bacterial abundance and DOC data collected (August 96 to May 97) by Schultz (1999) at VIMS were used for model validation. The bacterial abundance data were collected from a site close to the region of this study. In order to convert bacterial abundance to bacterial

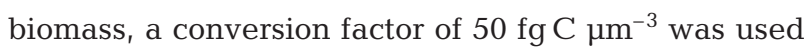
(Fagerbakke et al. 1996). Field data were not available for validation of heterotrophic flagellate + ciliate densities. Data for heterotrophic flagellate densities collected by Kindler (1991) were used for the validation. The EPA Chesapeake Bay Program monitoring data collected at a station (WE4.2) near the mouth of the York River were used for model validation of micro- and mesozooplankton. The abundances of these heterotrophs were converted to biomass using the conversion factors of $9.3 \mathrm{ng}$ $\mathrm{cell}^{-1}$ for microzooplankton and $9.3 \mu \mathrm{g} \mathrm{cell}^{-1}$ for mesozooplankton (Moloney \& Field 1991). POC data (May 1995 to March 1996) collected at the mouth of the York River by E. Canuel (VIMS) were used as validation data for POC concentrations. 
Sensitivity analysis. Sensitivity analysis was performed to examine how sensitive the model output was to specified changes $( \pm 20 \%)$ in the values of all constants and parameters used in the model. Model sensitivity was estimated as the root mean square deviation (RMS) between the daily values of state variables from nominal model runs $\left(N_{k}\right)$ and the outputs from sensitivity runs $\left(S_{k}\right)$ for $3 \mathrm{yr}$ simulations $(n=1095 \mathrm{~d})$ and was computed as:

$$
\mathrm{RMS}=\sqrt{\frac{1}{n} \sum_{k=1}^{n}\left(N_{k}-S_{k}\right)^{2}}
$$

In order to determine the effects of constant and parameter variations, the percent change in outputs was calculated based on comparisons between RMS and the means of each state variable for the nominal runs.

\section{RESULTS}

\section{Model validation \\ Forcing variables}

A comparison of functional fits and field data for the principal forcing variables, solar radiation, water temperature, and top-bottom salinity difference, shows generally good agreement, although variation in the mean daily solar radiation was especially prominent and not captured by the functional fits used in the model (Fig. 3). Field data for mean daily solar radiation and surface temperature were collected at VIMS. The salinity difference between surface and bottom waters was calculated from EPA monitoring data (Stn WE4.2) collected from 1994 to October 1994. It is difficult to validate functional fits for top-to-bottom salinity differences since few data were available for the York River. However, the function used to model salinity difference was previously verified based on field data (June to September 1985) by Eldridge \& Sieracki (1993).

\section{State variables}

The plankton ecosystem model was simulated for 3 yr and model predictions of state variable concentrations for the third year were used for validation. The simulated state variables for nominal model runs were compared to field measurements. Good agreement was generally shown in terms of range and temporal distributions of phytoplankton and nutrient state variables (Figs. 4 \& 5). The model output for total chlorophyll generally followed field data, except for the peaks observed during February and March (Fig. 4A). Simulated microphytoplankton densities matched very closely field observations (Fig. 4B). For nanophytoplankton, simulation out- put was similar to that of field concentrations, except for the peak observed during February and March (Fig. 4C). Simulated picophytoplankton concentrations generally followed the pattern of field measurements (Fig. 4D).

The modeled heterotrophic bacterial biomass in a unit volume $\left(\mathrm{m}^{3}\right)$ was close to that of measured bacterial biomass (Fig. 4E). The minimum concentrations during winter predicted by the model corresponded to field observations. It was difficult to validate simulated heterotrophic flagellate + ciliate biomass, since very few data for protozoan biomass were available for the York River. However, the range of predicted protozoan biomass (Fig. 4F) was within that of heterotrophic flagellate biomass alone measured by Kindler (1991), and possibly underestimates total protozoan biomass. Simulated concentrations of microzooplankton were dis-
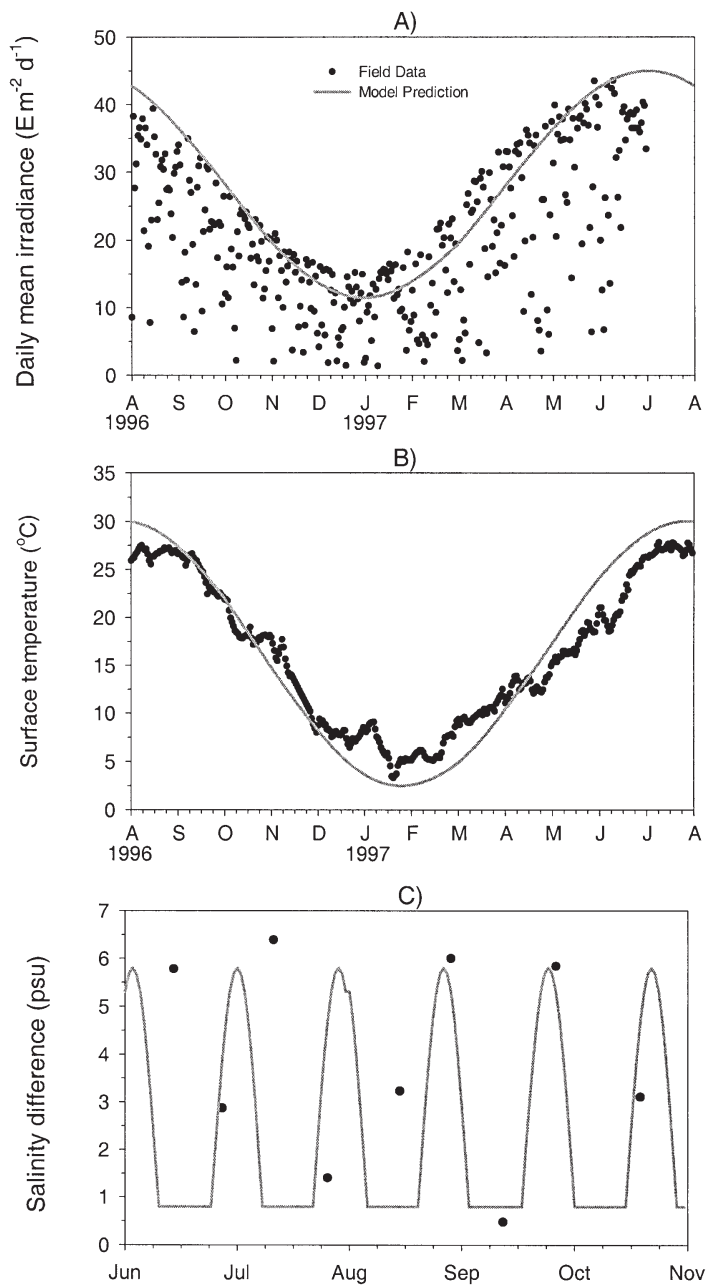

Fig. 3. Comparison of model predictions with observed field data for (A) surface daily PAR and (B) temperature collected at Virginia Institute of Marine Science, Gloucester Point, from August 1996 to July 1997. Salinity difference between surface and bottom waters (C) was calculated from US EPA Chesapeake Bay Program monitoring data (Stn WE4.2) collected from June 1994 to October 1994 

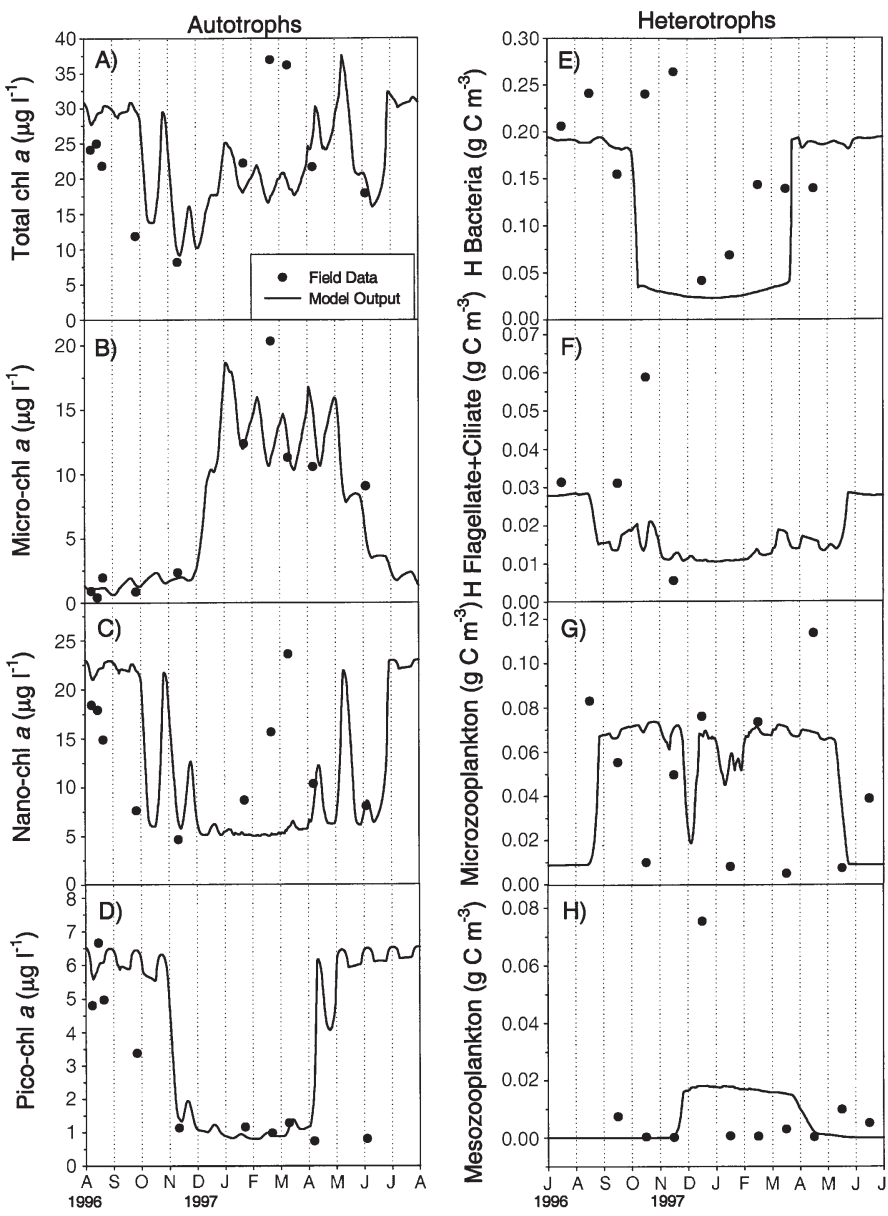

Fig. 4. Validation results for size-fractionated chl a (total, micro-, nano- and pico-), heterotrophic bacteria, heterotrophic flagellates + ciliates, and micro- and mesozooplankton in the mesohaline zone of the York River estuarine system. Field chl a data were collected from August 1996 to June 1997. Heterotrophic bacteria data were collected by Schultz (1999) and flagellate biomass (Kindler 1991) alone is shown in Fig. 4F. EPA monitoring data were used for micro- and mesozooplankton biomass

tributed within the range of measured concentrations which fluctuated greatly over the annual cycle (Fig. 4G). Simulated mesozooplankton biomass was comparable to field measurements, except for peak observed in December (Fig. 4H).

Like protozoan biomass, it was difficult to validate POC concentrations, since few data were available for comparison, but it appears that the model underestimates York River concentrations based on these very limited observations (Fig. 5A). Measured DOC concentrations did not vary greatly over an annual cycle, whereas simulated DOC concentrations revealed a seasonal pattern: low concentrations during the warm season and higher during the cold season, although the range (ca. 1 to $4 \mathrm{~g} \mathrm{C} \mathrm{m}^{-3}$ ) is relatively small (Fig. 5B). The modeled dissolved inorganic nitrogen (DIN), ammo- nium, and nitrate + nitrite concentrations showed good agreement with field data (Fig. 5C,D,E). The pattern of simulated orthophosphate concentrations generally followed measured concentrations, except for the peak observed in August 1996 (Fig. 5F). In general, the model results for nutrients fluctuated greatly with a frequency of less than a month, which was not reflected in the field data.

\section{Model sensitivity analysis}

The constants and parameters tested for model sensitivity included optimum light, cell mass, mortality rate, exudation rate, grazer preference, bed-shear velocity, fraction of sloppy feeding, fraction of egestion, leaching rate, grazing loss rate (POC), C:N ratio, denitrification, and C:P ratio. A total of 45 constants and parameters were tested, and only 11 parameters produced $\geq 10 \%$ change in the 3 yr average concentration of the state variables (microphytoplankton, micro + mesozooplankton, POC, ammonium and orthophosphate) relative to the nominal run (Table 4). This result suggests that the ecosystem model is relatively robust to parameter variations.
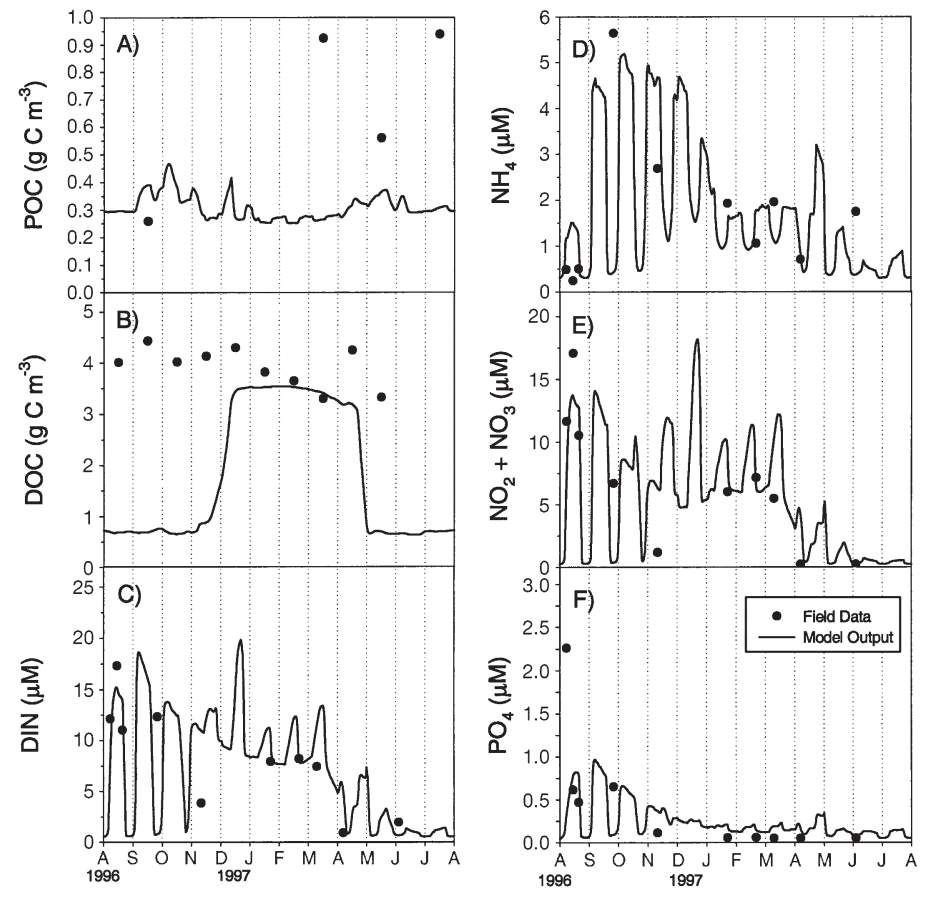

Fig. 5. Validation results for particulate organic carbon (POC), dissolved organic carbon (DOC) and nutrients (dissolved inorganic nitrogen, ammonium, nitrite + nitrate and orthophosphate) in the mesohaline zone of the York River estuarine system. POC was collected from May 1995 to March 1996 by E. Canuel, and DOC was collected by Schultz (1999). Observed nutrient data are from Sin et al. (2000) 
Table 4. Results (average RMS and \% change) of sensitivity analyses for state variables given $\pm 20 \%$ changes in parameter values. -: \% change < $10 \%$. PP: picophytoplankton; NP: nanophytoplankton; MP: microphytoplankton; HB: heterotrophic bacteria; HFC: heterotrophic flagellate + ciliates; Z1: microzooplankton, Z2: mesozooplankton; N1: ammonium; N2: nitrite + nitrate; P: orthophosphate

\begin{tabular}{|c|c|c|c|c|c|c|c|c|c|c|c|c|}
\hline \multirow{2}{*}{ Parameters } & \multirow[b]{2}{*}{ PP } & \multirow[b]{2}{*}{ NP } & \multirow[b]{2}{*}{ MP } & \multirow[b]{2}{*}{ HB } & \multirow[b]{2}{*}{$\mathrm{HFC}$} & \multicolumn{2}{|c|}{ State variable } & \multirow[b]{2}{*}{ POC } & \multirow[b]{2}{*}{ DOC } & \multirow[b]{2}{*}{ N1 } & \multirow[b]{2}{*}{$\mathrm{N} 2$} & \multirow[b]{2}{*}{$\mathrm{P}$} \\
\hline & & & & & & Z1 & $\mathrm{Z} 2$ & & & & & \\
\hline Optimum light $\left(I_{0}\right)$ & - & - & - & & & & & & & & & \\
\hline Exudation rate $\left(r_{\mathrm{ex}}\right)$ & - & - & - & & & & & & & & & \\
\hline Grazer preference $\left(P_{i j}\right)$ & - & - & - & - & - & - & & & & & & \\
\hline Cell mass $(M)$ & - & - & $1.02 / 15$ & - & - & - & $0.001 / 17$ & & & & & \\
\hline Mortality rate $\left(r_{\mathrm{m}}\right)$ & - & - & - & - & - & - & $0.002 / 28$ & & & & & \\
\hline Bed shear velocity $\left(u_{*}\right)$ & - & - & $0.86 / 12$ & - & - & $0.008 / 17$ & $7-$ & - & - & - & - & - \\
\hline Fraction of sloppy feeding $\left(f_{\mathrm{sf}}\right)$ & & & & & - & - & $0.002 / 30$ & & & & & \\
\hline Fraction of egestion $\left(f_{\mathrm{eg}}\right)$ & & & & & - & - & $0.002 / \mathbf{3 0}$ & & & & & \\
\hline Grazing by fishes (Z2M) & & & & & & & $0.001 / 21$ & & & & & \\
\hline Grazing loss rate $\left(r_{10}\right)$ & & & & & & & & - & & & & \\
\hline Leaching rate $\left(r_{1}\right)$ & & & & & & & & $.039 / 13$ & - & & & \\
\hline C:N ratio $\left(f_{\mathrm{C}: \mathrm{N}}\right)$ & & & & & & & & & & $0.003 / 13$ & - & \\
\hline Denitrification & & & & & & & & & & - & - & \\
\hline C:P ratio $\left(f_{\mathrm{C}: \mathrm{P}}\right)$ & & & & & & & & & & & & $0.0008 / 10$ \\
\hline
\end{tabular}

Small cells (pico- and nanophytoplankton) were insensitive to changes in all parameters, whereas large cells (microphytoplankton) were sensitive to change in cell size $(M)$ and bed-shear velocity $\left(u_{*}\right)$, exhibiting 14 and $12 \%$ change in average concentration respectively.

Heterotrophic bacteria, protozoans (flagellates + cilates) were insensitive to changes in the parameters, whereas microzooplankton responded to change in bed-shear velocity, as did the microphytoplankton. Unlike other heterotrophs, mesozooplankton were highly sensitive to most parameters tested. They showed high sensitivity ( $\geq 20 \%$ ) to loss terms such as mortality, sloppy feeding, egestion, and loss to higher consumers (Z2M). Change in cell size also produced changes close to $20 \%$.

POC was sensitive to changes in the loss term leaching rate $\left(r_{1}\right)$ but not to changes in the loss rate by grazing or to bed-shear velocity ( $r_{10}$ : Table 4$)$. DOC and nitrate were not sensitive to changes in leaching rate and bed-shear velocity. Ammonium was sensitive to the change in $\mathrm{C}: \mathrm{N}$ ratio for heterotrophs. Nitrite + nitrate was not sensitive to denitrification rate or to bed-shear velocity. Orthophosphate concentration was sensitive to changes in the C:P ratio, but it was not sensitive to bed-shear velocity. The actual parameter values are given in Appendix 1.

\section{DISCUSSION}

The microbial food web has become considered a principal component influencing water-column processes, and has been incorporated into modeling efforts of plankton food webs (e.g. Pace et al. 1984, Fasham et al. 1990, 1999, Ducklow \& Fasham 1992, Baretta-Bekker et al. 1994) since the 'microbial loop' concept was introduced by Pomeroy (1974) and Azam et al. (1983). Moloney \& Field (1989) analyzed data from the literature and presented allometric relationships between biological properties and body size. The general size-scale relationship has been used to simulate dynamics of plankton food webs (Moloney \& Field 1991, Painting et al. 1993, Armstrong 1994, Hurtt \& Armstrong 1996, Gin et al. 1998). This approach simplifies the process of parameter calibration for various size-class components in an aquatic food-web system, reducing the number of parameters to be estimated (Ducklow 1994). Size-based ecosystem models provide a more complete simulation tool for understanding the structure and function of pelagic ecosystems compared to simple models, in which the entire system is modeled as a single phytoplankton and zooplankton population. However, the allometric approach alone may greatly reduce the explanatory capability of the ecosystem model while it simplifies the problem of parameter estimation (Wetzel 1994). For the model given here, allometric relationships were employed for estimating maximum growth rate (Eq. 11), half saturation constants (Eq. 14), and the sinking rate of phytoplankton to differentiate the processes based on cell size. The size-dependence of optimum light intensity has not been well established to date. For this model, different values of optimal light intensity $\left(I_{0}\right)$ were used for each size class of phytoplankton to account for any size-dependence of the parameters. Lower light optima were selected for large cells (cf. Laws 1975), and the values were determined by model calibration. 
The York River ecosystem model also employed density-dependent feedback-control-terms, a priori derivations based on testable underlying assumptions (e.g. Wiegert 1979). The ecosystem model employs these derivations rather than mechanistic or empirical equations for carbon flows between predators and prey, and also between heterotrophic bacteria and DOC. These a priori derivations are considered superior to simple mechanistic or empirical equations for exploring the interactions among biotic components, especially predator-prey type interactions (Wetzel 1994).

Incorporation of hydrodynamic processes including advection and diffusion is also essential in estuarine ecosystem process-modeling, since estuaries represent complex environments in which freshwater and tidal energy inputs interact to affect biological and chemical processes. Estuaries in the mid-Atlantic region are characterized as partially-mixed (Beardsley \& Boicourt 1983), with longitudinal density gradients that result in baroclinic circulation superimposed on barotropic flow forced by river-discharge (Hansen \& Rattray 1965). Effects of estuarine circulation on plankton dynamics have been documented in previous studies (Malone et al. 1980, Haas et al. 1981). The importance of tidal mixing in plankton dynamics have been investigated more recently using estuarine-processes models (e.g. Cloern 1991, Eldridge \& Sieracki 1993, Koseff et al. 1993, Vidergar et al. 1993, Lucas et al. 1998). However, the incorporation of longitudinal advection into estuarine ecosystem models without linking to hydrodynamic models is relatively scarce compared to tidal mixing (e.g. Peterson \& Festa 1984, Li et al. 1998, Lucas et al. 1999). The ecosystem model presented here includes advection and diffusion by incorporating empirical equations to estimate residual velocities in $x$ and $z$ directions as in Table 3 and diffusion terms reflecting spring-neap, tidally induced stratification and destratification. Approximation of the physical description is simple and not as realistic as other multidimensional hydrodynamic models, but this approach does provide a technique for investigating direct effects of hydrodynamic processes on the phytoplankton and nutrient dynamics in the York River estuary through modeling analyses.

The results of model validation (Figs. 3 to 5 ) indicated that the ecosystem model captures to a large extent the dynamics of the principal components of the phytoplankton community and nutrients. Based on the results of the model sensitivity analysis (Table 4), the model is also considered relatively robust, since it was not highly sensitive to changes in most parameters. Therefore, the model could be used to examine various hypotheses put forward from previous studies concerning the controls and limits on phytoplankton and nutrient dynamics in the York River estuary (Sin et al. 1999, 2000). Although the model given here is a useful tool for analyzing sea- sonal variations of water-column processes within the scope of the modeling efforts, it has limitations in predicting the behavior of the entire system. The model represents only the mesohaline zone of the York River estuary. Also, simulation of bottom-layer dynamics ultimately needs to be included to describe nutrient fluxes at the sediment-water interface and interactions between phytoplankton and benthos in the system. Preference for ammonium by phytoplankton (Eq. 24) may need to be replaced by a competitive inhibition equation (e.g. Fasham et al. 1990), since Eq. (24) does not completely terminate the uptake of nitrite + nitrate when ammonium is abundant and nitrite + nitrate is scarce. The present model uses a fixed carbon:chlorophyll ratio (see Appendix 1), although the ratio is highly variable as a function of ambient light and nutrient conditions (Cloern et al. 1995). Considering the complexity of the ecosystem presented here, refinement in the DOC pool (i.e. refractory and labile) may also be required.

In summary, we have developed a tidally-averaged, size-structured ecosystem model that incorporates feedback-control terms and physical mechanisms including advection and diffusion with a neap-spring, fortnightly tidal cycle for the study of plankton dynamics in the mesohaline zone of the York River estuary. Feedbackcontrol terms are incorporated to better describe the interactions among biotic components, especially predator-prey interactions. Incorporation of physical mechanisms, especially longitudinal advection, leads to better understanding of the direct effects of physical processes on phytoplankton and nutrient dynamics. Few plankton ecosystem models have incorporated the physical mechanisms thought to exercise control over many biological processes in estuarine systems. General size-scale relationships for plankton dynamics were used to provide a straightforward modeling approach for the ecosystem model. The model presented in this paper also was accompanied by studies of long-term historical and field data to better understand phytoplankton and nutrient dynamics in an estuarine system (Sin et al. 1999, 2000). This resulted in a parallel structure between the modeling and other basic studies. Due to the complexity of interactions between phytoplankton and other plankton and between phytoplankton and the highly variable physical-chemical environment, it is difficult to identify the major controlling factors for the estuarine phytoplankton community by the analyses of historical and field data alone. Model validation for forcing and state variables suggested that the ecosystem-process model captures the phytoplankton and nutrient dynamics and is suitable for additional analyses of lower York River estuarine processes including the investigation of mechanisms controlling phytoplankton dynamics and the effects of nutrient inputs on the York River system in Virginia. The results also indicate that a combination of 
allometric relationships, density-dependent feedbackcontrol terms and hydrodynamic descriptions determined by empirical relationships provides a suitable approach for plankton-ecosystem modeling efforts in an estuarine system influenced by freshwater and tidal energy inputs. The York River system can be considered as a weakly eutrophic system compared with other tributaries in the Chesapeake Bay. However, nitrate and total phosphorus loads have increased significantly in the Pamunkey River (one of 2 rivers forming the York) over the period July 1989 to December 1995 (Bell et al. 1996). The York River system may become more eutrophic over the next decade as anthropogenic input of nutrients increases due to projected high population growth rates and land-use conversion (Corish et al. 1995). With anticipated refinements following these modeling studies, the model can be used to study the behavior of the ecosystem in response to potential changes in nutrient input. In a companion paper (Sin \& Wetzel 2002), we use the model to investigate controls on phytoplankton and nutrient dynamics in the York River estuary.

Acknowledgements. We are indebted to Dr H. W. Ducklow, Dr A. Y. Kuo, Dr K. Park, and anonymous reviewers for their constructive discussions and insights which greatly improved the manuscript. We also thank Dr J. Shen for technical assistance at the stage of model development. This research was supported in part by grants to R.L.W. from the US EPA Chesapeake Bay Program (CB993267-02-1) and AMOCO, Inc., Yorktown, Virginia. This is contribution number 2445 from the Virginia Institute of Marine Science, School of Marine Science of the College of William and Mary, Virginia.

Appendix 1. Initial values for state variables and parameter values employed in the ecosystem model; Symbol ${ }^{a}$ represents state variables in the Fortran90 codes whereas Symbol $^{\text {b }}$ denotes state variables used in the text

\begin{tabular}{|c|c|c|c|c|}
\hline Description & Symbol $^{a}$ & Symbol $^{b}$ & Value & Source \\
\hline \multicolumn{5}{|l|}{ State variables: initial conditions } \\
\hline Picophytoplankton & $\mathrm{X}(1)$ & $\mathrm{PP}(t)$ & $6.0 \mathrm{mg} \mathrm{chl} \mathrm{a} \mathrm{\textrm {m } ^ { - 3 }}$ & $\operatorname{Sin}(1998)$ \\
\hline Nanophytoplankton & $X(2)$ & $\mathrm{NP}(t)$ & $18.0 \mathrm{mg} \mathrm{chl} \mathrm{a} \mathrm{m}^{-3}$ & Sin (1998) \\
\hline Microphytoplankton & $X(3)$ & $\mathrm{MP}(t)$ & $1.0 \mathrm{mg} \mathrm{chl} \mathrm{a} \mathrm{m} \mathrm{m}^{-3}$ & $\operatorname{Sin}(1998)$ \\
\hline Heterotrophic bacteria & $X(4)$ & $\operatorname{HB}(t)$ & $0.18 \mathrm{~g} \mathrm{C} \mathrm{m}^{-3}$ & Kindler (1991) \\
\hline Flagellates \& ciliates & $\mathrm{X}(5)$ & $\operatorname{HFC}(t)$ & $0.01 \mathrm{~g} \mathrm{C} \mathrm{m}^{-3}$ & Kindler (1991) \\
\hline Microzooplankton & $\mathrm{X}(6)$ & $\mathrm{Z} 1(t)$ & $0.01 \mathrm{~g} \mathrm{C} \mathrm{m}^{-3}$ & EPA monitoring data \\
\hline Mesozooplankton & $X(7)$ & $\mathrm{Z} 2(t)$ & $0.002 \mathrm{~g} \mathrm{C} \mathrm{m}^{-3}$ & EPA monitoring data \\
\hline Particulate organic carbon & $X(8)$ & $\mathrm{POC}(t)$ & $0.60 \mathrm{~g} \mathrm{C} \mathrm{m}^{-3}$ & Canuel (unpubl. data) \\
\hline Dissolved organic carbon & $\mathrm{X}(9)$ & $\mathrm{DOC}(t)$ & $2.65 \mathrm{~g} \mathrm{C} \mathrm{m}^{-3}$ & Schultz (1999) \\
\hline Ammonium & $\mathrm{X}(10)$ & $\mathrm{N} 1(t)$ & $5.63 \mu \mathrm{M}$ & Sin (1998) \\
\hline Nitrite + nitrate & $\mathrm{X}(11)$ & $\mathrm{N} 2(t)$ & $0.07 \mu \mathrm{M}$ & Sin (1998) \\
\hline Orthophosphate & $\mathrm{X}(12)$ & $\mathrm{P}(t)$ & $2.26 \mu \mathrm{M}$ & Sin (1998) \\
\hline \multicolumn{5}{|l|}{ Parameters and coefficients } \\
\hline Time step & $\mathrm{dt}$ & & $0.0625 \mathrm{~d}$ & Calculation \\
\hline Starting time & tzero & & $1.0 \mathrm{~d}$ & Calculation \\
\hline Ending time & tend & & $1095.0 \mathrm{~d}$ & Calculation \\
\hline Optimum light for picophytoplankton & xIo(1) & $I_{\mathrm{o}}$ & $20.0 \mathrm{E} \mathrm{m}^{-2} \mathrm{~d}^{-1}$ & Calibration \\
\hline Optimum light for nanophytoplankton & $\mathrm{xIo}(2)$ & $I_{\mathrm{o}}$ & $5.0 \mathrm{E} \mathrm{m}^{-2} \mathrm{~d}^{-1}$ & Calibration \\
\hline Optimum light for microphytoplankton & xIo(3) & $I_{\mathrm{o}}$ & $1.0 \mathrm{E} \mathrm{m}^{-2} \mathrm{~d}^{-1}$ & Calibration \\
\hline Mass of picophytoplankton cell & $\mathrm{xM}(1)$ & $M$ & $0.088 \mathrm{pg}$ & Moloney \& Field (1991) \\
\hline Mass of nanophytoplankton cell & $\mathrm{xM}(2)$ & $M$ & $16.0 \mathrm{pg}$ & Moloney \& Field (1991) \\
\hline Mass of microphytoplankton cell & $\mathrm{xM}(3)$ & M & $2800.0 \mathrm{pg}$ & Moloney \& Field (1991) \\
\hline Mass of heterotrophic bacteria cell & hetM(1) & $M$ & $0.088 \mathrm{pg}$ & Moloney \& Field (1991) \\
\hline Mass of heterotrophic flagellate+ciliate cell & hetM(2) & $M$ & $9.3 \mathrm{pg}$ & Moloney \& Field (1991) \\
\hline Mass of microzooplankton individual & hetM(3) & $M$ & $9300.0 \mathrm{pg}$ & Moloney \& Field (1991) \\
\hline Mass of mesozooplankton individual & hetM(4) & $M$ & $9.3 \times 10^{6} \mathrm{pg}$ & Moloney \& Field (1991) \\
\hline Denitrification rate & rdenit & & $0.1 \mathrm{~d}^{-1}$ & Assumption \\
\hline $\mathrm{C}: \mathrm{N}$ ratio & CNrat & $f_{\mathrm{C}: \mathrm{N}}$ & 6.0 & DiToro et al. (1971) \\
\hline $\mathrm{C}: \mathrm{P}$ ratio & CPrat & $f_{\mathrm{C}: \mathrm{P}}$ & 42.0 & Redfield (1958) \\
\hline $\mathrm{C}: \mathrm{N}$ ratio for heterotrophs & hCNrat & & 5.0 & Newell \& Linley (1984) \\
\hline C:chl a ratio & cchl & & 50.0 & DiToro et al. (1971) \\
\hline Mortality rate of phytoplankton & $\mathrm{rm}$ & $r_{\mathrm{m}}$ & $1.0-10.0 \%$ & Calibration \\
\hline Exudation rate of phytoplankton & rex & $r_{\mathrm{ex}}$ & $1.0-10.0 \%$ & Calibration \\
\hline Leaching rate of POC & $\mathrm{rl}$ & $r_{1}$ & $20 \%$ & Calibration \\
\hline Grazing loss rate of POC & rlo & $r_{\mathrm{lo}}$ & $10 \%$ & Calibration \\
\hline Fraction of sloppy feeding & fsf & $f_{\mathrm{sf}}$ & $10 \%$ & Calibration \\
\hline Fraction of egestion by grazers & feg & $f_{\text {eg }}$ & $10 \%$ & Calibration \\
\hline Mortality rate of mesozooplankton & Z2M & $\mathrm{Z} 2 \mathrm{M}$ & $25 \%$ & Calibration \\
\hline
\end{tabular}


Appendix 1 (continued)

\begin{tabular}{|c|c|c|c|c|}
\hline Description & Symbol $^{\mathrm{a}}$ & Symbol $^{\mathrm{b}}$ & Value & Source \\
\hline Air density & airden & $\rho_{a}$ & $1.2 \times 10^{-3} \mathrm{~g} \mathrm{~cm}^{-3}$ & Park \& Kuo (1993) \\
\hline Drag coefficient & dgcoeff & $C_{10}$ & $1.3 \times 10^{-3}$ & Park \& Kuo (1993) \\
\hline Shear velocity & shrvel & $u_{*}$ & $0.01 \mathrm{~m} \mathrm{~s}^{-1}$ & Calibration \\
\hline Surface area of surface layer & As(1) & & $4.81 \times 10^{6} \mathrm{~m}^{2}$ & Calculation \\
\hline Surface area of bottom layer & $\operatorname{As}(2)$ & & $2.41 \times 10^{6} \mathrm{~m}^{2}$ & Calculation \\
\hline Water volume of surface layer & wvol(1) & & $40.40 \times 10^{6} \mathrm{~m}^{3}$ & Calculation \\
\hline Water volume of bottom layer & wvol(2) & & $18.32 \times 10^{6} \mathrm{~m}^{3}$ & Calculation \\
\hline Conversion factor for time & sdconv & & 86400.0 & Calculation \\
\hline Grazer preference for picophytoplankton & $\operatorname{pij}(1)$ & $P_{i j}$ & 0.2 & Calibration \\
\hline Grazer preference for nanophytoplankton & $\operatorname{pij}(2)$ & $P_{i j}$ & 0.2 & Calibration \\
\hline Grazer preference for microphytoplankton & $\operatorname{pij}(3)$ & $P_{i j}$ & 0.2 & Calibration \\
\hline Grazer preference for bacteria & $\operatorname{pij}(4)$ & $P_{i j}$ & 0.8 & Calibration \\
\hline Grazer preference for flagellates + ciliates & $\operatorname{pij}(5)$ & $P_{i j}$ & 0.8 & Calibration \\
\hline Grazer preference for microzooplankton & $\operatorname{pij}(6)$ & $P_{i j}$ & 0.8 & Calibration \\
\hline Donor threshold for picophytoplankton & aij(1) & $A_{i j}$ & $2.0 \mathrm{mg} \mathrm{chl} \mathrm{a} \mathrm{m}{ }^{-3}$ & Assumption \\
\hline Donor threshold for nanophytoplankton & $\operatorname{aij}(2)$ & $A_{i j}$ & $8.6 \mathrm{mg} \mathrm{chl} \mathrm{a} \mathrm{m}^{-3}$ & Assumption \\
\hline Donor threshold for microphytoplankton & $\operatorname{aij}(3)$ & $A_{i j}$ & $2.0 \mathrm{mg} \mathrm{chl} \mathrm{a} \mathrm{m}^{-3}$ & Assumption \\
\hline Donor threshold for bacteria & $\operatorname{aij}(4)$ & $A_{i j}$ & $0.04 \mathrm{~g} \mathrm{C} \mathrm{m}^{-3}$ & Assumption \\
\hline Donor threshold for flagellates + ciliates & $\operatorname{aij}(5)$ & $A_{i j}$ & $0.03 \mathrm{~g} \mathrm{C} \mathrm{m}^{-3}$ & Assumption \\
\hline Donor threshold for microzooplankton & $\operatorname{aij}(6)$ & $A_{i j}$ & $0.009 \mathrm{~g} \mathrm{C} \mathrm{m}^{-3}$ & Assumption \\
\hline Donor threshold for mesozooplankton & $\operatorname{aij}(7)$ & $A_{i j}$ & $0.002 \mathrm{~g} \mathrm{C} \mathrm{m}^{-3}$ & Assumption \\
\hline Donor threshold for POC & $\operatorname{aij}(8)$ & $A_{i j}$ & $0.30 \mathrm{~g} \mathrm{C} \mathrm{m}^{-3}$ & Assumption \\
\hline Donor threshold for DOC & $\operatorname{aij}(9)$ & $A_{i j}$ & $0.90 \mathrm{~g} \mathrm{C} \mathrm{m}^{-3}$ & Assumption \\
\hline Donor threshold for ammonium & aij(10) & $A_{i j}$ & $0.50 \mu \mathrm{M}$ & Assumption \\
\hline Donor threshold for nitrite + nitrate & aij(11) & $A_{i j}$ & $0.71 \mu \mathrm{M}$ & Assumption \\
\hline Donor threshold for orthophosphate & $\operatorname{aij}(12)$ & $A_{i j}$ & $0.16 \mu \mathrm{M}$ & Assumption \\
\hline Donor limit for picophytoplankton & gij(1) & $G_{i j}$ & $0.70 \mathrm{mg} \mathrm{chl} \mathrm{a} \mathrm{m}^{-3}$ & Sin $(1998)$ \\
\hline Donor limit for nanophytoplankton & $\operatorname{gij}(2)$ & $G_{i j}$ & $4.60 \mathrm{mg} \mathrm{chl} \mathrm{a} \mathrm{m}{ }^{-3}$ & Sin (1998) \\
\hline Donor limit for microphytoplankton & gij(3) & $G_{i j}$ & $0.8 \mathrm{mg} \mathrm{chl} \mathrm{a} \mathrm{m}^{-3}$ & Sin (1998) \\
\hline Donor limit for bacteria & gij(4) & $G_{i j}$ & $0.02 \mathrm{~g} \mathrm{C} \mathrm{m}^{-3}$ & Kindler (1991) \\
\hline Donor limit for flagellates + ciliates & gij(5) & $G_{i j}$ & $0.01 \mathrm{~g} \mathrm{C} \mathrm{m}^{-3}$ & Kindler (1991) \\
\hline Donor limit for microzooplankton & $\operatorname{gij}(6)$ & $G_{i j}$ & $0.007 \mathrm{~g} \mathrm{C} \mathrm{m}^{-3}$ & EPA monitoring data \\
\hline Donor limit for mesozooplankton & $\operatorname{gij}(7)$ & $G_{i j}$ & $0.001 \mathrm{~g} \mathrm{C} \mathrm{m}^{-3}$ & EPA monitoring data \\
\hline Donor limit for POC & gij(8) & $G_{i j}$ & $0.20 \mathrm{~g} \mathrm{C} \mathrm{m}^{-3}$ & Canuel (unpubl. data) \\
\hline Donor limit for DOC & gij(9) & $G_{i j}$ & $0.6 \mathrm{~g} \mathrm{C} \mathrm{m}^{-3}$ & Schultz (1999) \\
\hline Donor limit for ammonium & gij(10) & $G_{i j}$ & $0.21 \mu \mathrm{M}$ & $\operatorname{Sin}(1998)$ \\
\hline Donor limit for nitrite + nitrate & gij(11) & $G_{i j}$ & $0.21 \mu \mathrm{M}$ & Sin (1998) \\
\hline Donor limit for orthophosphate & gij(12) & $G_{i j}$ & $0.032 \mu \mathrm{M}$ & Sin (1998) \\
\hline Recipient threshold for picophytoplankton & ajj(1) & $A_{j j}$ & $5.50 \mathrm{mg} \mathrm{chl} \mathrm{a} \mathrm{m}{ }^{-3}$ & Assumption \\
\hline Recipient threshold for nanophytoplankton & ajj(2) & $A_{j j}$ & $20.6 \mathrm{mg} \mathrm{chl} \mathrm{a} \mathrm{m}^{-3}$ & Assumption \\
\hline Recipient threshold for microphytoplankton & ajj(3) & $A_{j j}$ & $20.3 \mathrm{mg} \mathrm{chl} \mathrm{a} \mathrm{m} \mathrm{m}^{-3}$ & Assumption \\
\hline Recipient threshold for bacteria & ajj(4) & $A_{j i}$ & $0.18 \mathrm{~g} \mathrm{C} \mathrm{m}^{-3}$ & Assumption \\
\hline Recipient threshold for flagellates + ciliates & ajj(5) & $A_{j j}$ & $0.05 \mathrm{~g} \mathrm{C} \mathrm{m}^{-3}$ & Assumption \\
\hline Recipient threshold for microzooplankton & ajj(6) & $A_{j j}$ & $0.065 \mathrm{~g} \mathrm{C} \mathrm{m}^{-3}$ & Assumption \\
\hline Recipient threshold for mesozooplankton & ajj(7) & $A_{j j}$ & $0.015 \mathrm{~g} \mathrm{C} \mathrm{m}^{-3}$ & Assumption \\
\hline Recipient threshold for POC & ajj(8) & $A_{j j}$ & $0.80 \mathrm{~g} \mathrm{C} \mathrm{m}^{-3}$ & Assumption \\
\hline Recipient threshold for DOC & ajj(9) & $A_{j j}$ & $3.0 \mathrm{~g} \mathrm{C} \mathrm{m}^{-3}$ & Assumption \\
\hline Recipient threshold for ammonium & ajj(10) & $A_{j j}$ & $5.0 \mu \mathrm{M}$ & Assumption \\
\hline Recipient threshold for nitrite + nitrate & ajj(11) & $A_{j j}$ & $14.3 \mu \mathrm{M}$ & Assumption \\
\hline Recipient threshold for orthophosphate & $\mathrm{ajj}(12)$ & $A_{j j}$ & $1.98 \mu \mathrm{M}$ & Assumption \\
\hline Max. recipient density for picophytoplankton & gjj(1) & $G_{j j}$ & $6.7 \mathrm{mg} \mathrm{chl} a \mathrm{~m}^{-3}$ & $\operatorname{Sin}(1998)$ \\
\hline Max. recipient density for nanophytoplankton & gjj(2) & $G_{j j}$ & $23.6 \mathrm{mg} \mathrm{chl} \mathrm{a} \mathrm{m} \mathrm{m}^{-3}$ & $\operatorname{Sin}(1998)$ \\
\hline Max. recipient density for microphytoplankton & gjj(3) & $G_{j j}$ & $22.3 \mathrm{mg} \mathrm{chl} \mathrm{a} \mathrm{m} \mathrm{m}^{-3}$ & $\operatorname{Sin}(1998)$ \\
\hline Max. recipient density for bacteria & gjj(4) & $G_{j j}$ & $0.20 \mathrm{~g} \mathrm{C} \mathrm{m}^{-3}$ & Kindler (1991) \\
\hline Max. recipient density for flagellates + ciliates & gjj(5) & $G_{j j}$ & $0.06 \mathrm{~g} \mathrm{C} \mathrm{m}^{-3}$ & Kindler (1991) \\
\hline Max. recipient density for microzooplankton & gjj(6) & $G_{j j}$ & $0.075 \mathrm{~g} \mathrm{C} \mathrm{m}^{-3}$ & EPA monitoring data \\
\hline Max. recipient density for mesozooplankton & gjj(7) & $G_{j j}$ & $0.02 \mathrm{~g} \mathrm{C} \mathrm{m}^{-3}$ & EPA monitoring data \\
\hline Max. recipient density for POC & gjj(8) & $G_{j j}$ & $1.0 \mathrm{~g} \mathrm{C} \mathrm{m}^{-3}$ & Canuel (unpubl. data) \\
\hline Max. recipient density for DOC & gjj(9) & $G_{j j}$ & $3.60 \mathrm{~g} \mathrm{C} \mathrm{m}^{-3}$ & Schultz (1999) \\
\hline Max. recipient density for ammonium & gjj(10) & $G_{j j}$ & $14.3 \mu \mathrm{M}$ & $\operatorname{Sin}(1998)$ \\
\hline Max. recipient density for nitrite + nitrate & gjj(11) & $G_{j j}$ & $35.7 \mu \mathrm{M}$ & Sin (1998) \\
\hline Max. recipient density for orthophosphate & gjj(12) & $G_{j j}$ & $2.26 \mu \mathrm{M}$ & Sin (1998) \\
\hline
\end{tabular}




\section{LITERATURE CITED}

Armstrong RA (1994) Grazing limitation and nutrient limitation in marine ecosystems: steady state solutions of an ecosystem model with multiple food chains. Limnol Oceanogr 39:597-608

Azam F, Fenchel T, Field JG, Gray JS, Meyer-Reil LA, Thingstad F (1983) The ecological role of water-column microbes in the sea. Mar Ecol Prog Ser 10:257-263

Baretta-Bekker JG, Riemann B, Baretta JW, Koch Rasmussen E (1994) Testing the microbial loop concept by comparing mesocosm data with results from a dynamical simulation model. Mar Ecol Prog Ser 106:187-198

Barthel KG (1983) Food uptake and growth efficiency of Eurytemora affinis (Copepoda: Calanoida). Mar Biol 74: 269-274

Beardsley RC, Boicourt WC (1983) On estuarine and continental shelf circulation in the middle Atlantic Bight. In: Warren BA, Wunsch C (eds) Evolution of physical oceanography. Massachusetts Institute of Technology, Cambridge, MA, p 198-233

Bell CF, Belval DL, Campbell JP (1996) Trends in nutrients and suspended solids at the fall line of five tributaries to the Chesapeake Bay in Virginia, July 1988 through June 1995. Water-Resources Investigations Report 96-4191. US Geological Survey, Richmond, VA

Biebl R, McRoy CP (1971) Plasmatic resistance and rate of respiration and photosynthesis of Zostera marina at different salinities and temperatures. Mar Biol 8:48-56

Cloern JE (1991) Tidal stirring and phytoplankton bloom dynamics in an estuary. J Mar Res 49:203-221

Cloern JE, Grenz C, Vidergar-Lucas L (1995) An empirical model of the phytoplankton chlorophyll: carbon ratiothe conversion factor between productivity and growth rate. Limnol Oceanogr 40:1313-1321

Corish K, Berman M, Hershner CH (1995) An economic analysis of the York River basin. Center for Coastal Management and Policy, Department of Resource Management and Policy, Virginia Institute of Marine Science, College of William and Mary, Gloucester Point, VA

Delgadillo-Hinojosa F, Gaxiola-Gastro G, Segovia-Zavala JA, Munoz-Barbosa A, Orozco-Borbon MV (1997) The effect of vertical mixing on primary production in a bay of the Gulf of California. Estuar Coast Shelf Sci 45:135-148

Denman KL, Gargett AE (1983) Time and space scales of vertical mixing and advection of phytoplankton in the upper ocean. Limnol Oceanogr 28:801-815

DiToro DM, O'Connor DJ, Thomann RV (1971) A dynamic model of phytoplankton populations in the SacramentoSan Joaquin delta. Adv Chem Ser 106:131-180

Ducklow HW (1994) Modeling the microbial food web. Microb Ecol 28:303-319

Ducklow HW, Fasham MJR (1992) Bacteria in the greenhouse: modeling the role of oceanic plankton in the global carbon cycle. In: Mitchell T (ed) New concepts in environmental microbiology. Wiley Liss Inc., New York, p 1-32

Eldridge PM, ME Sieracki (1993) Biological and hydrodynamic regulation of the microbial food web in a periodically mixed estuary. Limnol Oceanogr 38(8):1666-1679

Eppley RW (1972) Temperature and phytoplankton growth in the sea. Fish Bull (Wash DC) 70:1063-1085

Fagerbakke KM, Heldal M, Norland S (1996) Content of carbon, nitrogen, oxygen, sulfur and phosphorus in native aquatic and cultured bacteria. Aquat Microb Ecol 10:15-27

Fasham MJR, Ducklow HW, McKelvie SM (1990) A nitrogenbased model of plankton dynamics in the oceanic mixed layer. J Mar Res 48:591-639
Fasham MJR, Boyd PW, Savidge G (1999) Modeling the relative contributions of autotrophs and heterotrophs to carbon flow at a Lagrangian JGOFS station in the Northeast Atlantic: the importance of DOC. Limnol Oceanogr 44: 80-94

Fenchel T (1974) Intrinsic rate of natural increase: the relationship with body size. Oecologia (Berl) 14:317-326

Gin KYH, Guo J, Cheong HF (1998) A size-based ecosystem model for pelagic waters. Ecol Model 112:53-72

Haas LW (1975) Plankton dynamics in a temperate estuary with observations on a variable hydrographic condition. PhD thesis, School of Marine Science, College of William and Mary, Gloucester Point, VA

Haas LW, Hastings SJ, Webb KL (1981) Phytoplankton response to a stratification-mixing cycle in the York River estuary during late summer. In: Neilson BJ, Cronin LE (eds) Estuaries and nutrients. The Humana Press, Clifton, NJ, p 619-636

Hamilton P (1977) On the numerical formulation of a time dependent multi-level model of an estuary, with particular reference to boundary conditions. In: Wiley M (ed) Estuarine processes: Vol II. Circulation, sediments and transfer of material in the estuary. Academic Press, New York, p 347-364

Hansen DV, Rattray M Jr (1965) Gravitational circulation in straits and estuaries. J Mar Res 23:104-122

Hayward D, Haas LW, Boon JD, Webb KL, Friedland KD (1986) Empirical models of stratification variations in the York River estuary, Virginia. USA. Coast Estuar Stud 17:346-367

Hurtt GC, Armstrong RA (1996) A pelagic ecosystem model calibrated with BATS data. Deep-Sea Res Part II 43: 653-683

Jaworski NA, Lear DW, Villa O Jr (1972) Nutrient management in the Potomac Estuary. Nutrients and eutrophication. Spec Symp Am Soc Limnol Oceanogr 1:246-272

Joint IR (1991) The allometric determination of pelagic production rates. J Plankton Res 13(Suppl):69-81

Kindler DD (1991) Contrasts between tidal freshwater and estuarine phytoplankton growth on intracellular and recycled nutrient pools over a summer-winter seasonal transition. MA thesis. School of Marine Science, The College of William and Mary, Gloucester Point, VA

Koseff JR, Holen JK, Monismith SG, Cloern JE (1993) Coupled effects of vertical mixing and benthic grazing on phytoplankton population in shallow, turbid estuaries. J Mar Res 51:843-868

Kristensen E (1994) Decomposition of macroalgae, vascular plants and sediment detritus in seawater: use of stepwise thermogravimetry. Biogeochemistry 26:1-24

Laws EA (1975) The importance of respiration losses in controlling the size distribution of marine phytoplankton. Ecology 56:419-426

Li M, Gargett A, Denman K (1998) Seasonal and interannual variability of estuarine circulation in a box model of the Strait of Georgia and Juan de Fuca Strait. Atmos Ocean 37:1-19

Lucas LV, Cloern JE, Koseff JR, Monismith SG, Thompson JK (1998) Does the Sverdrup critical depth model explain bloom dynamics in estuaries? J Mar Res 56:375-415

Lucas LV, Koseff JR, Monismith SG, Cloern JE, Thompson JK (1999) Processes governing phytoplankton blooms in estuaries. II. The role of horizontal transport. Mar Ecol Prog Ser 187:17-30

Malone TC, Ducklow HW (1990) Microbial biomass in the coastal plume of Chesapeake Bay: phytoplankton-bacterioplankton relationships. Limnol Oceanogr 35:296-312

Malone TC, Neale PJ, Boardman D (1980) Influences of estu- 
arine circulation on the distribution and biomass of phytoplankton size fractions. In: Kennendy V (ed) Estuarine perspectives. Academic Press, New York, p 249-262

Miller CA, Landry MR (1984) Ingestion-independent rates of ammonium excretion by the copepod Calanus pacificus. Mar Biol 78:265-270

Moloney CL, Field JG (1989) General allometric equations for rates of nutrient uptake, ingestion and respiration in plankton organisms. Limnol Oceanogr 34:1290-1299

Moloney CL, Field JG (1991) The size-based dynamics of plankton food webs. I. A simulation model of carbon and nitrogen flows. J Plankton Res 13:1003-1038

Monod J (1942) Recherches sur la croissance des cultures bacteriennes. Herman et Cie, Paris

Newell CL, Linley EAS (1984) Significance of microheterotrophs in the decomposition of phytoplankton: estimates of carbon and nitrogen flow based on the biomass of plankton communities. Mar Ecol Prog Ser 16:105-119

Nowicki BL, Requintina E, van Keuren D, Kelly JR (1997) Nitrogen losses through sediment denitrification in Boston Harbor and Massachusetts Bay. Estuaries 20:626-639

Odum HT (1983) Systems ecology: an introduction. John Wiley \& Sons, New York

Pace ML, Glasser JE, Pomeroy LR (1984) A simulation analysis of continental shelf food webs. Mar Biol 82:47-63

Painting SJ, Moloney CL, Lucas MI (1993) Simulation and field measurements of phytoplankton-bacteria-zooplankton interactions in the southern Benguela upwelling region. Mar Ecol Prog Ser 100:55-69

Park K, Kuo AY (1993) A vertical two-dimensional model of estuarine hydrodynamics and water quality. Special Report in Applied Marine Science and Ocean Engineering No. 321. School of Marine Science, Virginia Institute of Marine Science, College of William and Mary, Gloucester Point, VA

Peters RH (1983) The ecological implications of body size. Cambridge University Press, Cambridge, New York, p 1-329

Peterson DH, Festa JF (1984) Numerical simulation of phytoplankton productivity in partially mixed estuaries. Estuar Coast Shelf Sci 19:563-589

Pomeroy LR (1974) The ocean's food web: a changing paradigm. BioScience 24:499-504

Pritchard DW (1965) Lectures on estuarine oceanography. The Johns Hopkins University, Chesapeake Bay Institute and Department of Oceanography. Baltimore, MD

Redfield AC (1958) The biological control of chemical factors in the environment. Am Sci 46:205-222

Schultz GE Jr (1999) Bacterial dynamics and community structure in the York River Estuary. PhD thesis, College of William and Mary, Gloucester Point, VA

Shen J, Boon JD, Kuo AY (1999) A modeling study of a tidal intrusion front and its impact on larval dispersion in the James River estuary, Virginia. Estuaries 22:681-692

Sin Y (1998) Ecosystem analysis of water column processes in the York River estuary, Virginia: historical records, field studies and modeling analysis. PhD thesis, College of William and Mary, Gloucester Point, VA

Editorial responsibility: Otto Kinne (Editor), Oldendorf/Luhe, Germany
Sin Y, Wetzel RL (2002) Ecosystem modeling analysis of sizestructured phytoplankton dynamics in the York River estuary, Virginia (USA). II. Use of a plankton ecosystem model for investigating controlling factors on phytoplankton and nutrient dynamics. Mar Ecol Prog Ser 228:91-101

Sin Y, Wetzel RL, Anderson IC (1999) Spatial and temporal characteristics of nutrient and phytoplankton dynamics in the York River estuary, Virginia: analyses of long term data. Estuaries 22:260-275

Sin Y, Wetzel RL, Anderson IC (2000) Seasonal variations of size fractionated phytoplankton along the salinity gradient in the York River estuary, Virginia (USA). J Plankton Res 22:1945-1960

Tamsalu R, Ennet P (1995) Ecosystem modeling in the Gulf of Finland. II. The aquatic ecosystem model FINEST. Estuar Coast Shelf Sci 41:429-458

Thomann R, Fitzpatrick J (1982) Calibration and verification of a mathematical model of the eutrophication of the Potomac Estuary. Hydro-Qual Inc., Mahwah, NJ

Vidergar LL, Koseff JR, Monismith SG (1993) Numerical models of phytoplankton dynamics for shallow estuaries. Proceedings of the 1993 National Conference on Hydraulic Engineering, San Francisco, July, 1993. American Society of Civil Engineers, New York, p 1025-1030

Wetzel RL (1994) Modeling the microbial loop: an estuarine modeler's perspective. Microb Ecol 28:331-334

Wetzel RL, Christian RR (1984) Model studies on the interactions among carbon substrates, bacteria and consumers in a salt marsh estuary. Bull Mar Sci 35:601-614

Wetzel RL, Meyers MB (1993) Ecosystem process-modeling of submersed aquatic vegetation in the lower Chesapeake Bay. Final report to United States Environmental Protection Agency Region III. Chesapeake Bay Program Office, School of Marine Science, Virginia Institute of Marine Science, College of William and Mary, Gloucester Point, VA

Wiegert RG (1973) A general ecological model and its use in simulating algal-fly energetics in a thermal spring community. In: Geier PW, Clark LR, Anderson DJ, Nix HA (eds) Insects: studies in population management, Vol. 1. Ecological Society of Australia, Canberra, (Occas Pap) p 85-102

Wiegert RG (1979) Population models: experimental tools for the analysis of ecosystems. In: Horn DJ, Mitchell R, Stairs GR (eds) Proceedings of a colloquium on analysis of ecosystems. Ohio State University Press, Columbus, $\mathrm{OH}$, p 239-275

Wiegert RG, Wetzel RL (1979) Simulation experiments with a 14-compartment salt marsh model. In: Dame RF (ed) Marsh-estuarine systems simulation, University of South Carolina Press, Columbia, DC, p 7-39

Wojcik FJ (1981) Monthly salinity data for the York River plotted by river mile by month. Data Report 17 . Virginia Institute of Marine Science, School of Marine Science, College of William and Mary, Gloucester Point, VA

Young RN, Southard JB (1978) Erosion of fine-grained marine sediment: sea-floor and laboratory experiments, Geol Soc Am Bull 89:663-672

Submitted: August 8, 2000; Accepted: April 24, 2001

Proofs received from author(s): February 12, 2002 